Article

\title{
Ecological Vulnerability of Adult Female Marine Turtles as Indicators of Opportunities for Regional Socioecosystem Management in the Southern Gulf of Mexico
}

\author{
María de los Angeles Liceaga-Correa ${ }^{1}$, Abigail Uribe-Martínez ${ }^{1, *}$ and Eduardo Cuevas ${ }^{1,2, *}$ \\ 1 Centro de Investigación y de Estudios Avanzados del Instituto Politécnico Nacional, Unidad Mérida, \\ Merida 97310, Mexico; maria.liceaga@cinvestav.mx \\ 2 Centro de Investigación de Ciencias Ambientales, Facultad de Ciencias Naturales, CONACYT- Universidad \\ Autónoma del Carmen, Ciudad del Carmen 24155, Mexico \\ * Correspondence: auribe@cigom.org (A.U.-M.); ecuevas@conacyt.mx (E.C.)
}

check for updates

Citation: Liceaga-Correa, M.d.1.A.; Uribe-Martínez, A.; Cuevas, E. Ecological Vulnerability of Adult Female Marine Turtles as Indicators of Opportunities for Regional Socioecosystem Management in the Southern Gulf of Mexico. Sustainability 2022, 14, 184. https://doi.org/10.3390/ su14010184

Academic Editors: Ileana Espejel, César Vázquez-González, Alejandro Espinoza Tenorio and Georges Seingier

Received: 19 October 2021

Accepted: 13 December 2021

Published: 24 December 2021

Publisher's Note: MDPI stays neutral with regard to jurisdictional claims in published maps and institutional affiliations.

Copyright: (C) 2021 by the authors. Licensee MDPI, Basel, Switzerland. This article is an open access article distributed under the terms and conditions of the Creative Commons Attribution (CC BY) license (https:// creativecommons.org/licenses/by/ $4.0 /)$.

\begin{abstract}
Planning for marine ecosystems management demands spatially explicit information about structural and functional components, in a tradeoff between including the most taxa and keeping it functional. Sentinel, umbrella, and surrogate taxa are strategic for developing indexes that account for other associated species and contribute to a sustainable administration of our seas. Marine turtles feature the former species descriptions, and the knowledge on their ecology contributes to design conservation and restoration strategies in regions they occupy, such as the Gulf of Mexico. Several administrative tools exist to govern marine territories for biodiversity conservation, and assessing how these tools interact with the ecological vulnerability of endangered species is crucial for improving public policies. We assessed the spatial interactions among ecological sensitivity, vulnerability, and the potential impacts on four marine turtle species in the southern Gulf of Mexico and northwestern Caribbean Sea with territorial management tools (natural protected areas, marine priority sites, and ecoregions). A small percentage of the most vulnerable areas is inside natural protected areas, while marine priority sites include a higher percentage. We identified spatial covering gaps that need to be addressed to ensure the conservation and recovery of these endangered species in the Gulf of Mexico and proposed key regions for maximizing territorial conservation.
\end{abstract}

Keywords: satellite telemetry; spatial ecology; ecological vulnerability; endangered species

\section{Introduction}

Management of natural spaces is a transdisciplinary challenge. Part of this challenge is to balance the occurrence of human activities (extractive and nonextractive) within ecosystem components, which must have optimal and functional conditions to enable ecological integrity in the long term. These conditions occur at distinct spatiotemporal scales and levels of organization [1,2], giving dynamic stability to the target entity adapted to delimited spaces where biological, physical, ecological, and anthropic processes occur and interact, and this space has been referred to as the socioecosystem $[3,4]$. Such a variety of processes contribute to strengthening the viability, resistance, and resilience of the system [5]. Healthy ecosystems represent certainty in terms of the environmental services that human communities perceive, including tangible and intangible ones; thus, assessing the contextual environmental conditions under which socioecosystem components occur is crucial for the long-term integrity and preservation of the complete system [6-9]. Evaluating the ecological vulnerability of biodiversity components is an essential aspect to determining the ecological integrity of a system [10].

The inherent complexity of large marine ecosystems (see https://ioc.unesco.org/ topics / large-marine-ecosystems accessed on 10 October 2021) has been examined through the study of surrogate groups or species, that is, groups with intrinsic features that make them usable as indicators or sentinels of the structural and functional complexity of the 
socioecosystems they occupy [11]. These indicators are a viable and low-cost strategy that is useful for understanding the spatiotemporal variation in the system, as well as for identifying the mean states and variability in biodiversity and its responses to human and environmental interactions in the long term [12,13]. Monitoring these species contributes to defining and implementing integral management strategies, including adaptive, ecosystembased, and co-management strategies that help increase the resilience of ecological and socioeconomic components (adapted from [11]). Thus, surrogate and sentinel species act as an umbrella for lower trophic level groups that interact within the same habitat and benefit from the implemented management actions [14]. Recently, green turtles (Chelonia mydas) were used as indicator species to identify the location of seagrass meadows and to improve estimates of their global distribution [15]; together with dugongs (Dugong dugon), these co-occurring species functioned to delineate areas to maximize species protection [16]. In both studies, these species functioned as an umbrella species and contributed to protecting the ecosystem that they occupy.

It is essential to obtain baseline values of ecological integrity indicators for a surrogate indicator group so that it can properly serve as a sentinel, and changes in the attributes of these indicators may indicate changes linked to alterations in the system. Such early detection may lead to more efficient adaptive management strategies and policies, as well as the optimization of economic and human resources for the implemented actions and provision of quantitative references for continuous monitoring [17].

Given that ecosystems are under multiple simultaneously occurring stressors, it is proposed that the cumulative ecological vulnerability to those stressors acting on a keystone biodiversity group be evaluated and a baseline reference for long-term monitoring be provided [18-20]. In this regards, marine turtles are a group of megavertebrates that are considered keystone species and indicator/sentinel species [11,21], and they occupy diverse ecological niches where they interact with benthic, nektonic, and pelagic communities in marine ecosystems, as well as with inland coastal ecosystems during their breeding seasons $[7,22,23]$. These species are highly sensitive to changes in their environments, both to anthropogenic and natural sources of impacts [24,25]. Additionally, their extensive migratory movements make them an important ecosystem component susceptible to impacts at multiple levels in the large Gulf of Mexico system; thus, they are representative sentinel and umbrella species [11,23].

Five species of marine turtles are widely distributed in the Gulf of Mexico and Western Caribbean; these species are the hawksbill (Eretmochelys imbricata), green (Chelonia mydas), Kemp's ridley (Lepidochelys kempii), loggerhead (Caretta caretta), and leatherback (Dermochelys coriacea) turtles [26]. Similar to apex predators, marine turtle populations and their critical habitats are under severe pressure that imperils their ecological integrity and the ecological functions they perform in the ecosystems they occupy [27-31]. Some of the key ecological functions performed by these species are maintaining the population balance of strong competitor species of sponges on coral reefs [14,32,33], potentially controlling noxious jellyfish populations that may compete with and impact industrial fisheries in oceanic regions [34,35], promoting carbon sequestration in seagrass meadows [36,37], fertilizing oligotrophic sandy beaches [6,38-40], etc.

Nesting marine turtles are the most studied population segment of these species because they are relatively easy to access. At adult stage, females and males frequently share foraging and residency habitats [22,26], so knowing where the former are established is a reasonable indicator of where adult marine turtle populations live.

The simultaneous action of multiple stressors on populations and ecosystems depletes marine turtle resistance and resilience while increasing their ecological vulnerability $[18,19]$. On the other hand, humans have implemented administrative strategies to provide legal protection to biodiversity, mainly through natural protected areas [41] and territorial ordinances aiming to decrease and, at best, eliminate the source of negative impacts on biodiversity and habitats [42] 
Therefore, assessing the cumulative potential impacts on and the ecological vulnerability of marine turtles and their habitats, in the context of the administrative instruments that regulate their habitat use, is imperative to the recovery and protection of their populations and habitats. These assessments will also positively impact other species and communities at lower biological organizational levels underneath the 'umbrella' that marine turtles represent, contributing to an integral approach for better informed sustainable use of the seas.

Satellite tracking technology has been used extensively in the conservation and management of marine turtles inhabiting the southern Gulf of Mexico and northwestern Caribbean Sea. Cuevas et al. [20] tracked green and hawksbill turtles and provided the basis for the ecological vulnerability approach used in subsequent studies. Liceaga-Correa et al. [43] expanded on this concept for interactions with oil spill scenarios by including tracking data for loggerhead and Kemp's ridley turtles. Uribe-Martínez et al. [44] also used telemetry data for these four species to investigate movement patterns and features of critical in-water habitats. The present study builds upon these earlier efforts by analyzing the ecological vulnerability and potential impact for marine turtle species with regards to comprehensive territorial management analyses.

Thus, the objectives of the current study were (i) to evaluate the potential impact of multiple threats to marine turtle-sensitive areas, (ii) to spatially quantify the cumulative ecological vulnerability of four marine turtle species, and (iii) to describe the territorial configuration of highly vulnerable areas in terms of administrative instruments (natural protected areas, energy industry exclusion areas, and no-fishing refuges) that regulate the area used by these species in the southern Gulf of Mexico.

\section{Materials and Methods}

\subsection{Study Area}

Our study area was delineated by the movement extension of satellite tracked marine turtles from 47 nesting beaches located in the Mexican states of Tamaulipas, Veracruz, Campeche, Yucatan, and Quintana Roo, in the southern Gulf of Mexico and northwestern Caribbean Sea $\left(12.0^{\circ}-30.5^{\circ} \mathrm{N}\right.$ and $\left.-78.65^{\circ}--23.85^{\circ} \mathrm{W}\right)$. These nesting beaches were selected based on their singular relevance in terms of the number of nests for each species [45] and taking into account the number of previously satellite tracked individuals from each of the nesting beaches [46-48].

\subsection{Satellite Tracking Data}

Processing for the satellite tracking data was described by Uribe-Martinez et al. [44], which provides the basis for the current analyses. The dataset includes 85 satellite transmitters (ARGOS system) that were deployed on an equal number of post-nesting females, distributed among the four species: hawksbills $(\mathrm{N}=21$, E. imbricata), greens $(\mathrm{N}=43$, C. mydas), loggerheads ( $\mathrm{N}=12, \mathrm{C}$. caretta), and Kemp's ridleys $(\mathrm{N}=9$, L. kempii). Sixty-eight percent $(\mathrm{N}=58)$ were TAM4510-3 Telonics, Inc., (Meza, AZ, USA) tags, $18 \%(\mathrm{~N}=15)$ were SPOT 352-B, and the rest $(\mathrm{N}=12)$ were SPLASH 10-309A. The last two models were by Wildlife Computers, Inc. (Redmond, WA, USA). Since these different models work with the same ARGOS system and we only needed the geographic coordinates of their locations for this study, the datasets derived from these tags were considered compatible, so the quality control and numerical processing was the same for all cases.

The selection of the nesting female to tag was random, as we surveyed the nesting beach during the night looking for a nesting female. After being found and having finished laying her eggs, we captured her and attached the transmitter following the procedure suggested by Gallegos-Fernández et al. [49]. The procedure consisted of cleaning the attachment region of the carapace at the central front region using sandpaper and manually removing any epibiont. The region is washed with freshwater, dried, and finally cleaned using pharmacy alcohol. The tags were glued to the carapace using fast cure epoxy glue (Devco 5 min(C), reinforced with fiber glass strips, and covered with epoxy clay (Loctite 
Magic Steel()). Finally, the satellite transmitter was covered using marine antifouling paint to delay the time that marine epibionts colonize the transmitter. After the glue, clay, and paint cured, the tagged individuals were released at the same point where they were captured.

The transmitted locations were collected through a telnet service provided by Collecte Localisation Satellite (CLS), and they were administrated using an R script [50] linked to an Access database.

When using the ARGOS location system, a large number of the records used to be location class (LC) A and B, as Uribe-Martínez et al. [44] described. While the size of the error ellipse of the latter LCs is larger than the others, they can also be accurate as the location is actually somewhere inside an error bi-variate ellipse around what is expected to be the real location point. As it is a common circumstance, CLS implemented the Kalman filter algorithm to improve the accuracy of all LCs in general [51]. Given this context, plus the fact of the large scale movements of these species [52], and the fact that other marine turtle satellite tracking studies in the Gulf of Mexico have also used all the LC records [53-55], we used LC records but $\mathrm{Z}$.

Additionally, the location datasets were filtered using the function vmask from the $\mathrm{R}$ argosfilter package [56], and any location on land, having as reference the Global Administrative Areas (https://gadm.org/ accessed on 23 August 2021), was deleted. Along the tracks, the post-nesting females occupied distinct habitats, named internesting (movements restricted close to their nesting beach), migrating (directed movement), and foraging (spatially restricted movements after migrating) life stages, and as during the time spent there their behavior and reproductive importance varies at each stage, we visually categorized all the used satellite tracked records [46,55,57].

\subsection{Ecological Vulnerability Assessment}

Following Cuevas et al. [20], we used the Conservation Action Plan tool [58] and spatial multicriteria analyses to evaluate the ecological vulnerability of these species to different threats along their distribution range in the Gulf of Mexico. Cuevas et al. [20] evaluated two marine turtle species (E. imbricata and C. mydas) in this same study area, but in this study, we expanded the understanding of the region by also evaluating the ecological vulnerability of $C$. caretta and L. kempii and describing the spatial configuration of the cumulative ecological vulnerability for the four species together.

Consistent with Cuevas et al. [20], we considered 'ecological vulnerability' as the condition in which at least one sensitive attribute of an object of interest (OI, in this case, hawksbill, green, loggerhead, and Kemp's ridley turtles) is exposed to a multilevel threat (modified from [59]). We evaluated the same six threats as Cuevas et al. [20] for the four species, expanding the knowledge for using territorial management tools.

To provide a brief description of the numerical approach, we include a description of the ecological vulnerability assessment [20] and the ecological indicators used for the calculations (Appendix A).

\subsection{Spatial Configuration in Terms of Territorial Administration}

Some of the territorial management tools were crossed with the individual species cumulative vulnerability and with the total cumulative ecological vulnerability to describe their spatial assemblages associated with the administrative tools.

We evaluated the spatial intersection among sensitive, potentially impacted, and vulnerable areas per marine turtle species with biologically important regions (North American Marine Ecoregions-Level II (NAMEL2, [60]), Mexican Priority Marine Sites (PMS, [61]), and the regional territorial marine plan (Regional Marine Ecological Ordering Program of the Gulf of Mexico y Mexican Caribbean, RMEOP, [62])). Additionally, natural protected areas (NPAs), a federally binding tool, were spatially assessed with ecologically vulnerable marine turtle areas. 
We evaluated the potential impact of threats associated with human extractive activities (oil platforms, seismic surveys, and fishing effort) to increase the understanding of spatial interactions with these imperiled species, aiming to promote better informed sustainable strategies in these industries.

The sensitivity, potential impact, and vulnerability values were grouped into four quartiles for categorical analyses, defined as very high (values $>0.75$ ), high (values between 0.5 and 0.75 ), medium (values between 0.25 and 0.5 ), and relevant (values $<0.25$ ).

This analysis aimed to determine what percentage of each quartile of sensitive and vulnerable areas per species is covered by any NPA, what percentage of sensitive and vulnerable areas per species is inside the PMS, and what ecoregion harbors the most vulnerable areas.

The intersection between highly ecologically vulnerable and sensitive areas for sentinel and umbrella species is an indicator of the territorial administrative status in terms of marine biodiversity conservation and management capabilities. This same analysis allowed the identification of critical gaps in terms of territorial protection that should be addressed soon by multisectoral efforts to strengthen marine biodiversity ecological integrity in the long term.

\section{Results}

The spatial analysis was done with more than 35 thousand location records, and the data delineated varied among species and beach origin. The location records classified as foraging were considered of high interest for marine biodiversity conservation as marine turtles are keystone species, meaning that a complex food web supports their presence in their feeding and residency areas.

\subsection{Ecological Vulnerability Assessment}

The most sensitive areas for marine turtles were located on the continental shelf, even when they were established at locations far from shore (Figure 1). The most sensitive areas for hawksbill turtles primarily occurred on the northern coast of Yucatan, foraging areas for this species, followed by some areas close to shore in the southern Campeche and northern Quintana Roo, both associated with internesting habitats (Figure 1a). Similarly, the green turtles were spatially condensed, and their most sensitive area was located at the northeastern corner of the peninsula, while secondary sensitive areas occurred in northwestern Yucatan and close to the coast of Veracruz, all of them associated with foraging stages (Figure 1b). Kemp's ridley individuals aggregated mostly in two medium-sized areas in northern Tamaulipas and Veracruz (Figure 1c), the former with the highest sensitivity values in the region and corresponding to foraging areas. These individuals also displayed a punctually important sensitive foraging area at an isolated bank on the Campeche Bank, western Yucatan Peninsula. Finally, loggerhead individuals had highly sensitive areas associated with internesting habitats in the central littoral part of Quintana Roo (eastern Yucatan Peninsula) and very highly sensitive foraging areas in the northwestern corner of the same peninsula (close to the Banks of Sisal) and off the coast of Tabasco in the southern Gulf of Mexico (Figure 1d). There was no major geographic correlation of highly/very highly sensitive areas among species. 

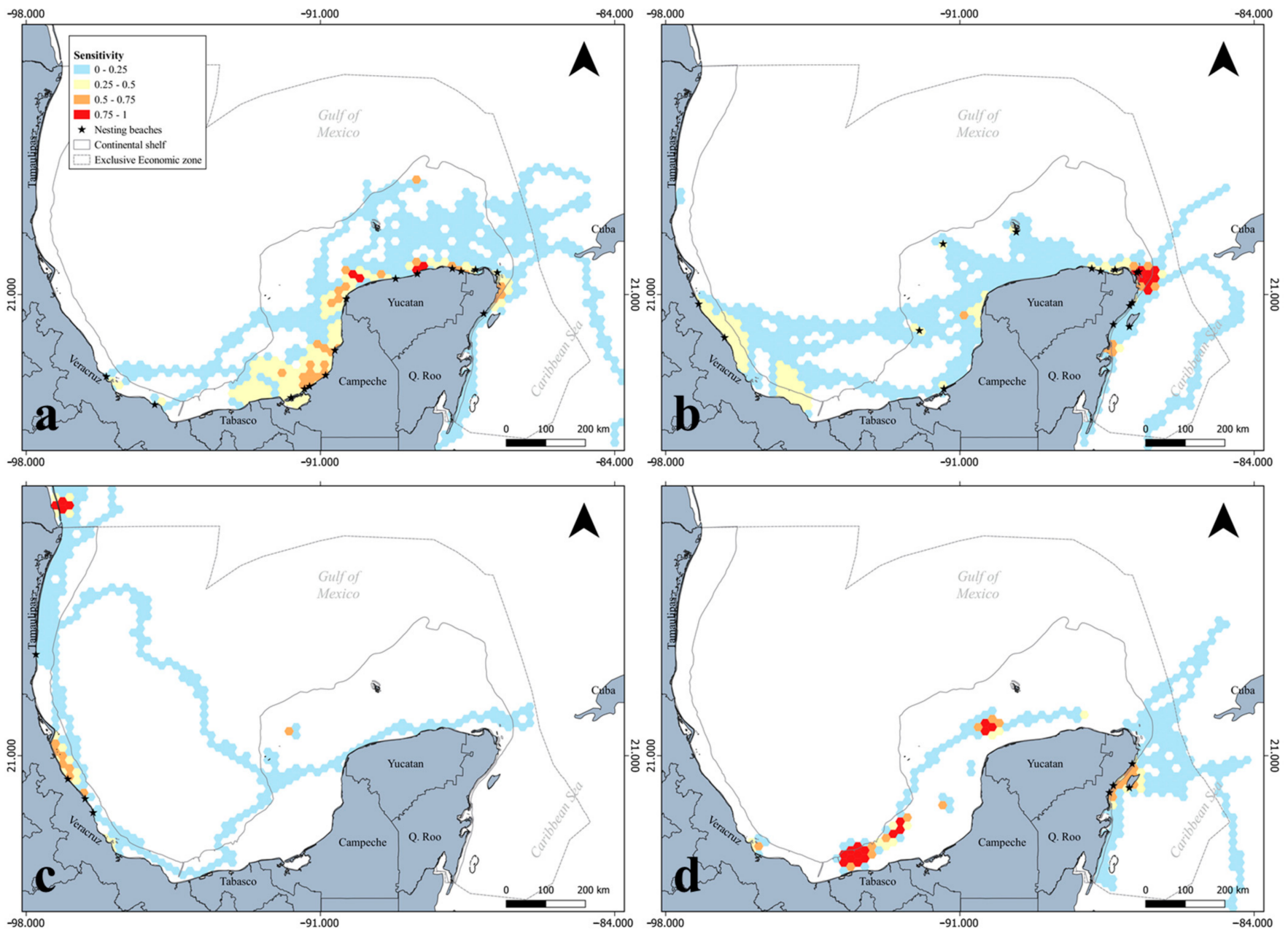

Figure 1. Sensitive areas formed by intersecting migration and feeding stages of satellite-tracked post-nesting hawksbill (a), green (b), Kemp's ridley (c), and loggerhead (d) individuals and their habitats in the southern and western Gulf of Mexico.

In terms of the spatial overlap between sensitive areas for marine turtles and threats, the spatial intersection with anthropic activities is of highest concern because of the socioenvironmental conflicts that may arise. The fishing effort indicator assessed in this study spatially interacted with sensitive areas for the four marine turtle species (Figure 2). The region with the highest potential impact was near the central littoral zone of Veracruz, where highly sensitive internesting areas for green (Figure 1b) and Kemp's ridley (Figure 1c) individuals are located $\left(10,530 \mathrm{~km}^{2}\right)$. Some small areas north of the Yucatan Peninsula $\left(1620 \mathrm{~km}^{2}\right)$ (Figure 2a) and on the coast of Tabasco (Figure $\left.2 \mathrm{~d}\right)\left(405 \mathrm{~km}^{2}\right)$ showed very high potential impact interactions with fishing efforts and sensitive foraging areas for hawksbills and loggerheads, respectively. In this methodological approach, the migratory corridors were assigned with relatively lower weight-sensitive values in comparison to internesting and foraging habitats (as individuals spend shorter time at any location in them compared to internesting areas where they spend months). Nevertheless, the potential impact of fishing efforts on these critical migratory habitats is not of minor concern, otherwise the migratory routes would not have even been delimited in this study. 

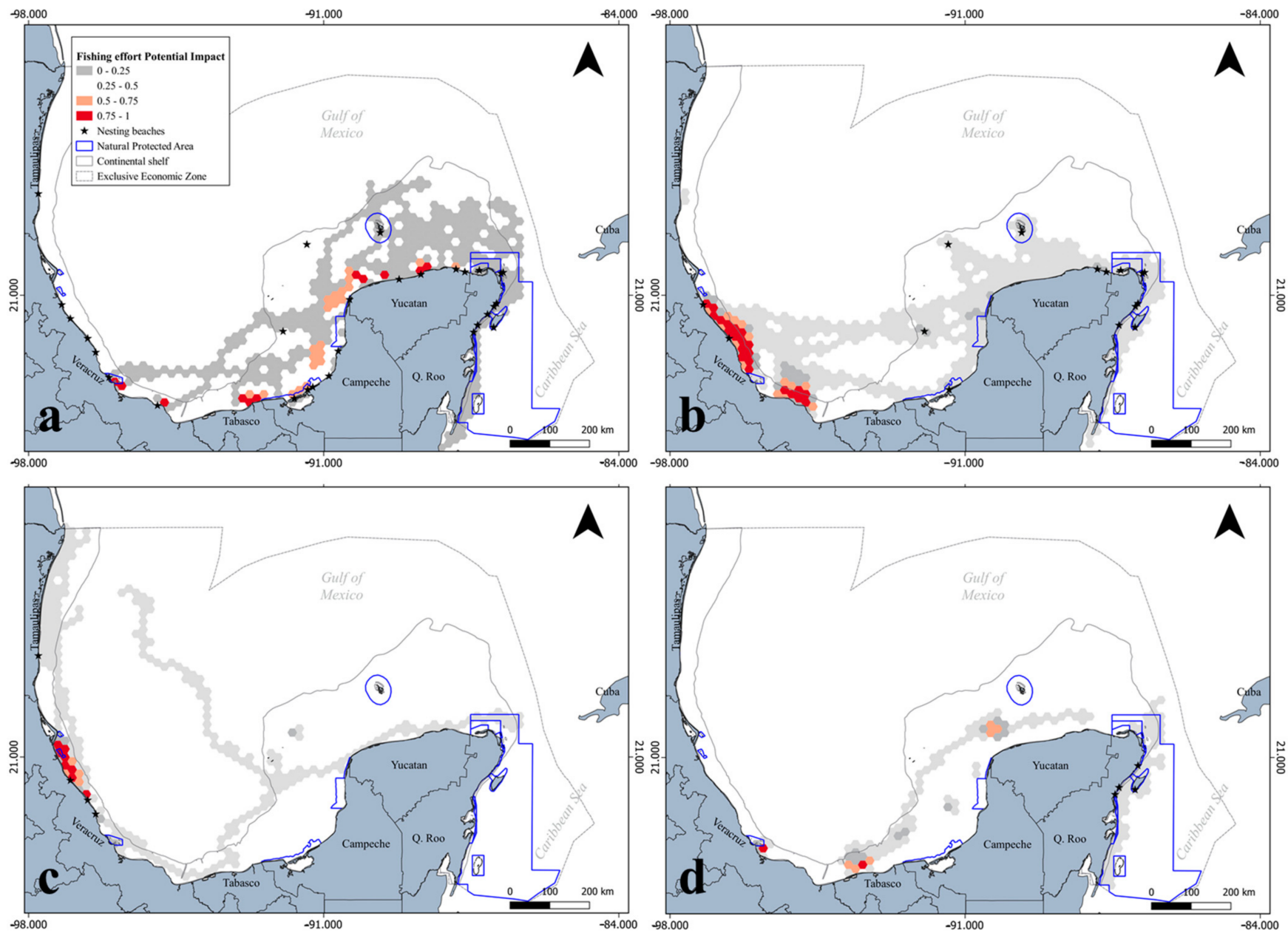

Figure 2. Spatial distribution of potential impact of fishing effort on hawksbill (a), green (b), Kemp's ridley (c), and loggerhead (d) individuals and their habitats in the southern and western Gulf of Mexico.

Similarly, the oil industry (seismic surveys and oil extraction platforms) interacted with sensitive marine turtle areas at a comparable spatial scale, with different intensities and distributions for each species (Figure 3). All the areas with high potential impacts were located on the continental shelf of the southern and western Gulf of Mexico, mainly associated with the oil extraction areas off southern Campeche (both internesting and foraging areas), as well as on the coast of Tabasco (foraging) and Veracruz (internesting). The marine turtle-sensitive areas on the northern and northeastern Yucatan Peninsula were mainly impacted by oil exploration seismic surveys, affecting foraging hawksbill (Figure 3a) and loggerhead (Figure $3 \mathrm{~d}$ ) individuals $\left(1215 \mathrm{~km}^{2}\right)$, with similar potential impact conditions for both species south of Campeche $\left(3240 \mathrm{~km}^{2}\right)$. In addition, high potential impact areas were identified in the central littoral zone of Veracruz for green (Figure 3b) and Kemp's ridley (Figure 3c) individuals during their internesting stages $\left(2835 \mathrm{~km}^{2}\right)$, intersecting seismic survey areas. 

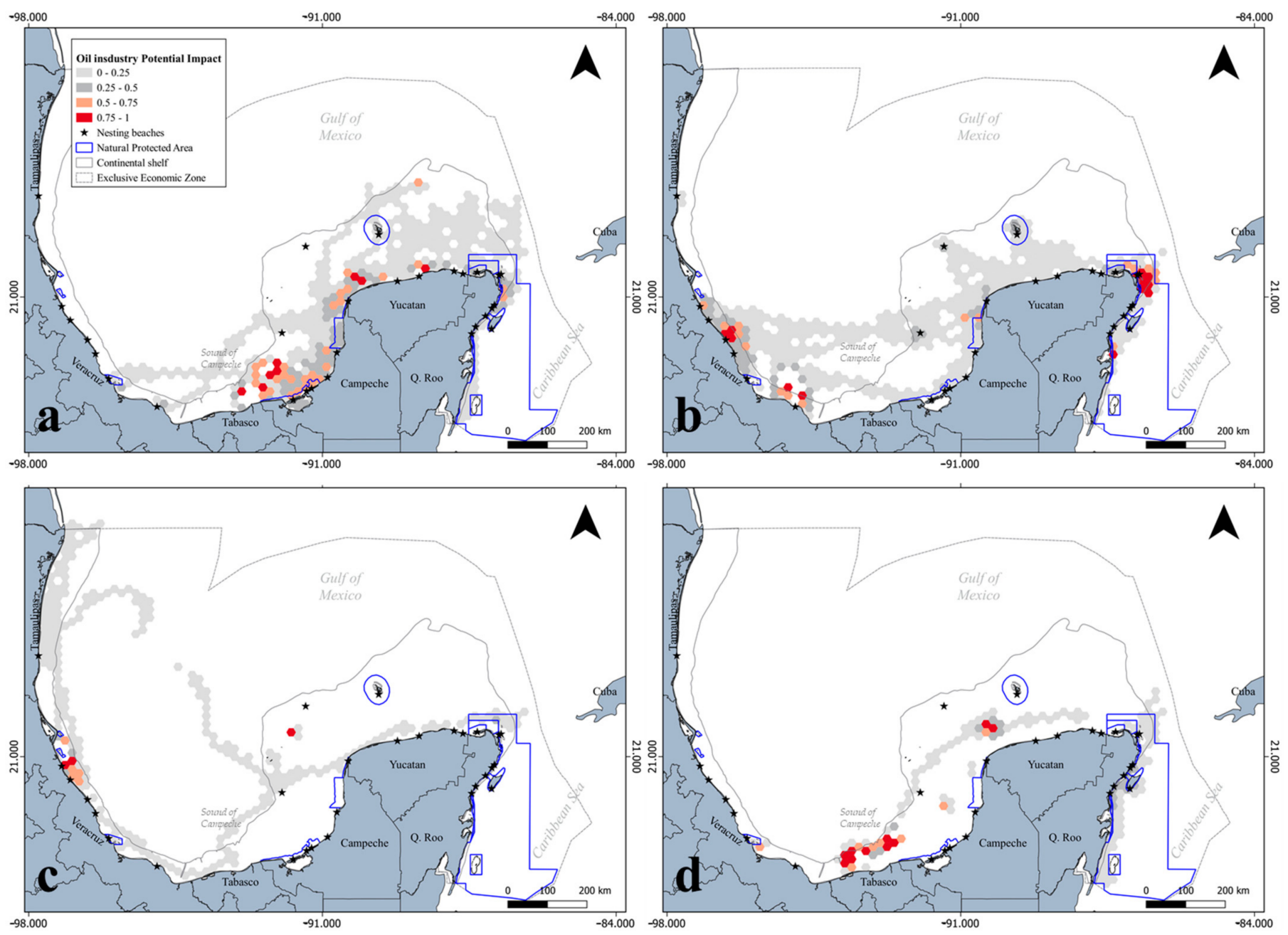

Figure 3. Spatial distribution of potential impact of oil industry-related activities on hawksbill (a), green (b), Kemp's ridley (c), and loggerhead (d) individuals and their habitats in the southern and western Gulf of Mexico.

There is a clear overlap between marine turtle-sensitive areas and moderate- to highintensity oil industry-associated activities, particularly on the continental shelf where shallow water drillings mostly occur in the southern Gulf of Mexico. This spatial overlap sets the stage for potentially important territorial socioenvironmental conflicts between conservation and the energy industry.

Considering the combined potential impacts of anthropic threats on each of the species, three major regions had the highest interactions (Figure 4). The largest area with the highest combined potential impact $\left(8500 \mathrm{~km}^{2}\right)$ occurred along the central and southern littoral areas of Veracruz (Figure $4 \mathrm{~b}, \mathrm{c}$ ), mainly impacting green (Figure $4 \mathrm{~b}$ ) and Kemp's ridley (Figure 4c) turtle internesting habitats, whilst the Sound of Campeche had discrete mediumsized patches of very high potential impact $\left(2430 \mathrm{~km}^{2}\right)$ for hawksbill (Figure 4a) and loggerhead (Figure 4d) internesting and foraging habitats, respectively. Finally, the third largest and very high combined potential impact area was located on the northeastern Yucatan Peninsula $\left(2430 \mathrm{~km}^{2}\right)$, where mainly green turtle individuals are established for foraging (Figure $4 b$ ). 

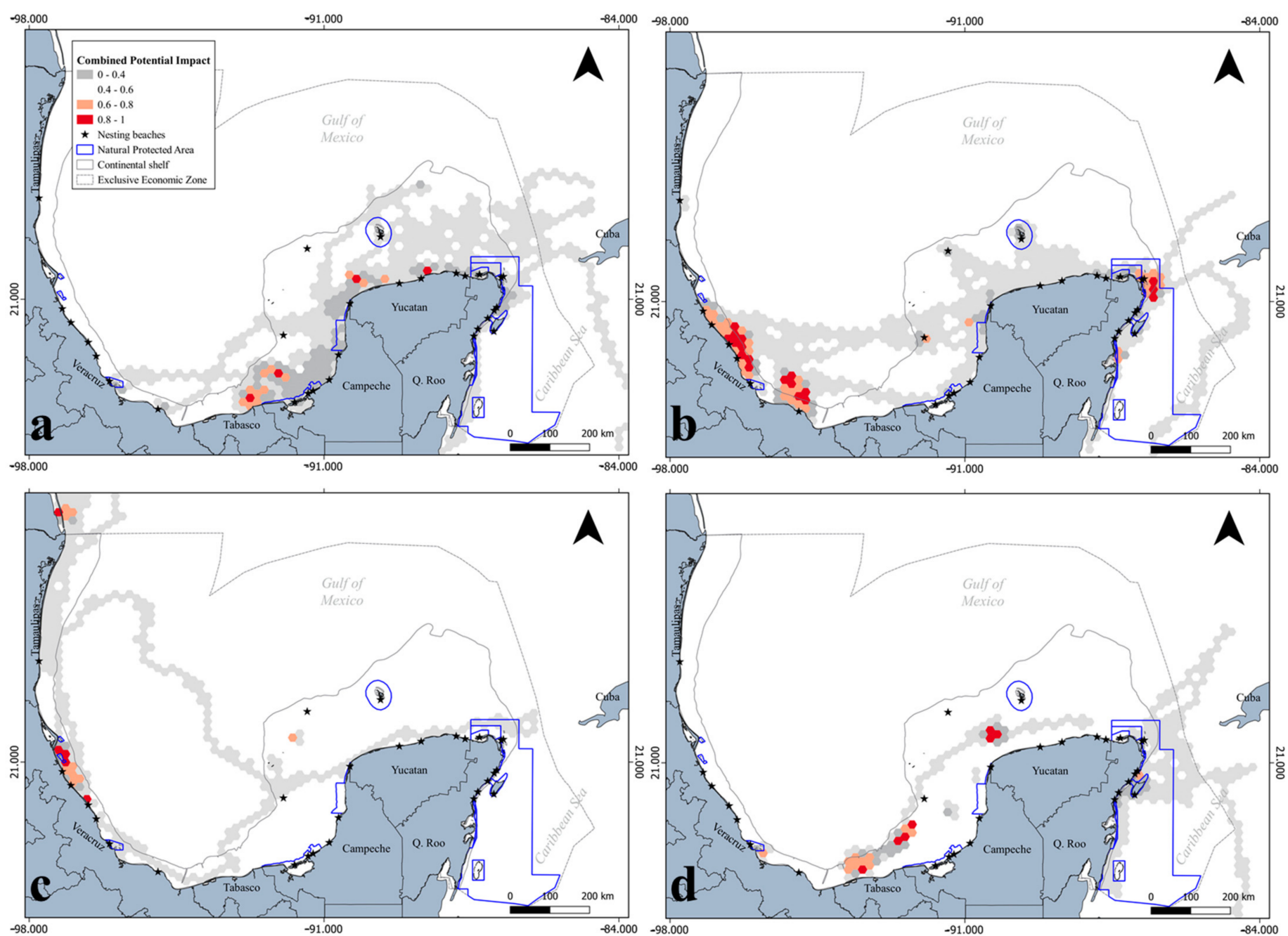

Figure 4. Spatial distribution of the combined potential impacts of anthropic threats on hawksbill (a), green (b), Kemp's ridley (c), and loggerhead (d) individuals and their habitats in the southern and western Gulf of Mexico.

This spatial configuration of the combined potential impacts on marine turtles provides a baseline description of the areas where marine ecosystems may also be imperiled by anthropic activities.

The spatial configuration of the cumulative ecological vulnerability was different for each marine turtle species (Figure S1). We only detected small patches $\left(405 \mathrm{~km}^{2}\right)$ of very highly vulnerable foraging areas for hawksbill turtles on the north coast of Yucatan (Figure S1a), while other foraging areas with medium and high vulnerability levels were mostly depicted on the western coast of the peninsula. The central and southern littoral zones of Veracruz harbored very high and highly vulnerable areas for green (Figure S1b) and Kemp's ridley (Figure S1c) individuals in their internesting stages. North of Tamaulipas was also a very high potentially cumulative impacted area for Kemp's ridley turtles while foraging. Finally, very highly vulnerable foraging areas occurred on the coast of Tabasco for loggerhead individuals, and highly vulnerable patches occurred at the northwestern corner of the same peninsula (Figure S1d). The Mexican Caribbean did not have areas with medium to very high levels of vulnerability because of the numeric effect (stability coefficient) that several natural protected areas have in the vulnerability equation (Appendix A, Equation (A1)). 
Finally, the spatially explicit depiction of cumulative ecological vulnerability (Appendix A, Equation (A5)) for the four marine turtle species combined occurred in the southern and western Gulf of Mexico (Figure 5). The very highly vulnerable areas were mainly located off the central-northern littoral zone of Veracruz $\left(1620 \mathrm{~km}^{2}\right)$ and a small patch $\left(405 \mathrm{~km}^{2}\right)$ on the northwestern part of the Yucatan Peninsula, whilst the highly vulnerable areas were located mainly off the northern littoral zone of Veracruz $\left(2430 \mathrm{~km}^{2}\right)$, off Tabasco and Terminos Lagoon $\left(2430 \mathrm{~km}^{2}\right)$ and on the northern Yucatan Peninsula $\left(1215 \mathrm{~km}^{2}\right)$. Areas with medium levels of vulnerability occurred in wider areas on the western and northern coasts of the Yucatan Peninsula.

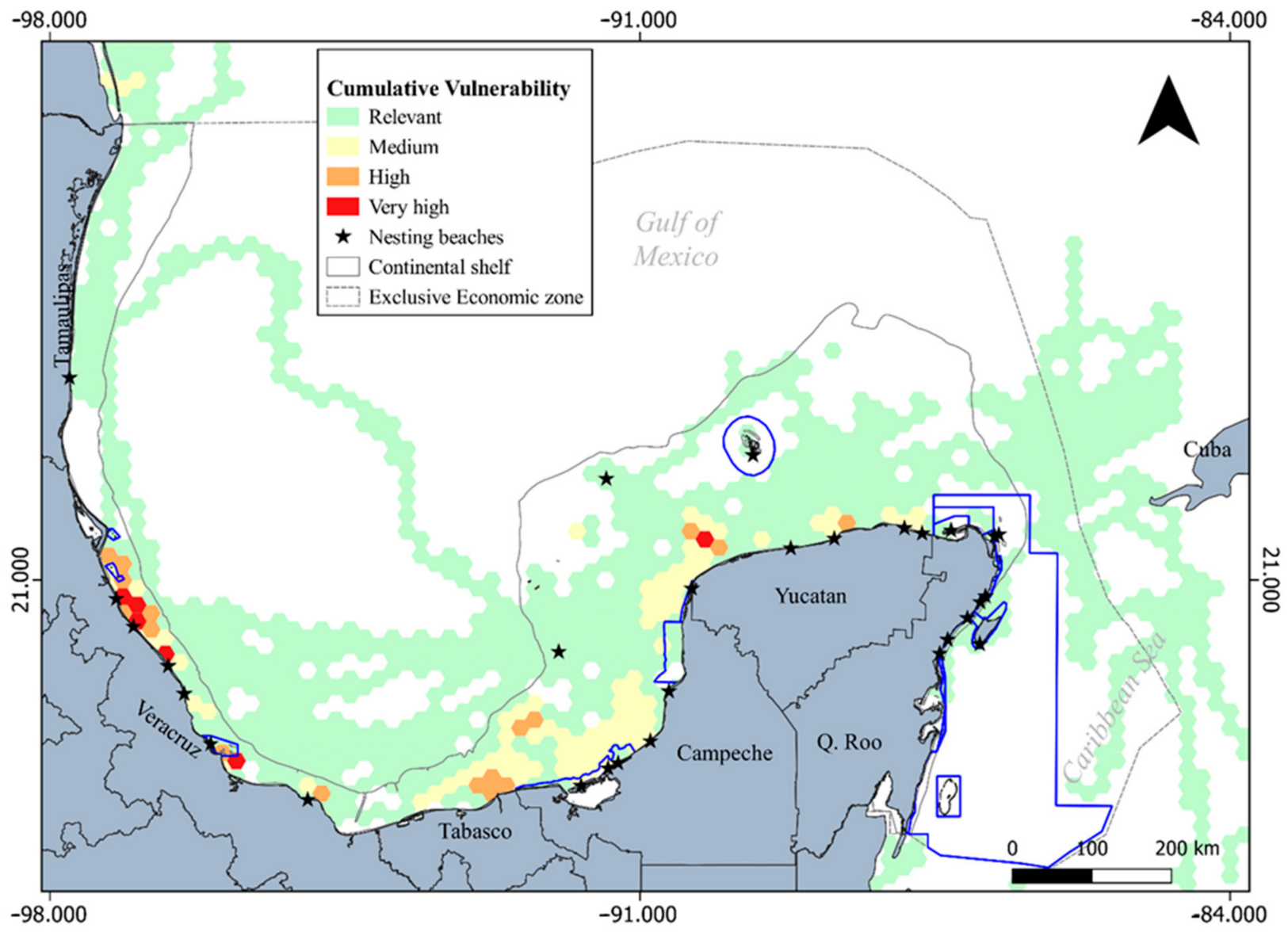

Figure 5. Spatial configuration of combined cumulative ecological vulnerability for hawksbill, green, Kemp's ridley, and loggerhead individuals and their habitats in the southern and western Gulf of Mexico.

\subsection{Spatial Configuration in Terms of Territorial Administration}

In addition to the spatial correlation between the sensitive areas for the four marine turtle species and the three anthropic threats evaluated in this study, administrative factors also affect the territorial configuration of these sentinel species in the Gulf of Mexico.

One of the most direct interests in terms of territorial configuration for biodiversity conservation is the percentage of critical habitats and ecosystems that are inside natural protected areas (Figure S2a). From the perspective of marine turtles as sentinel and keystone species in marine ecosystems, the distribution of the most sensitive areas varied among the species in southern Gulf of Mexico and northwestern Caribbean. The geographic scope of the NPAs mostly encompassed close-to-shore areas that were mainly associated with green turtles (Figure 6a). All the very highly $(0.75-1.0)$ sensitive areas for this species were inside an NPA and encompassed an average of $53 \%( \pm 23.76)$ of the highly sensitive areas $(0.5-0.75)$ and an average of $35 \%( \pm 14.90)$ of the areas with medium levels of sensitivity $(0.25-0.50)$ for all marine turtles together. This positive impact on marine ecosystems mainly occurs 
in the Mexican Caribbean, where most NPAs exist, while there is a substantial marine territorial protection gap in the southern and western Gulf of Mexico (Figure 5).

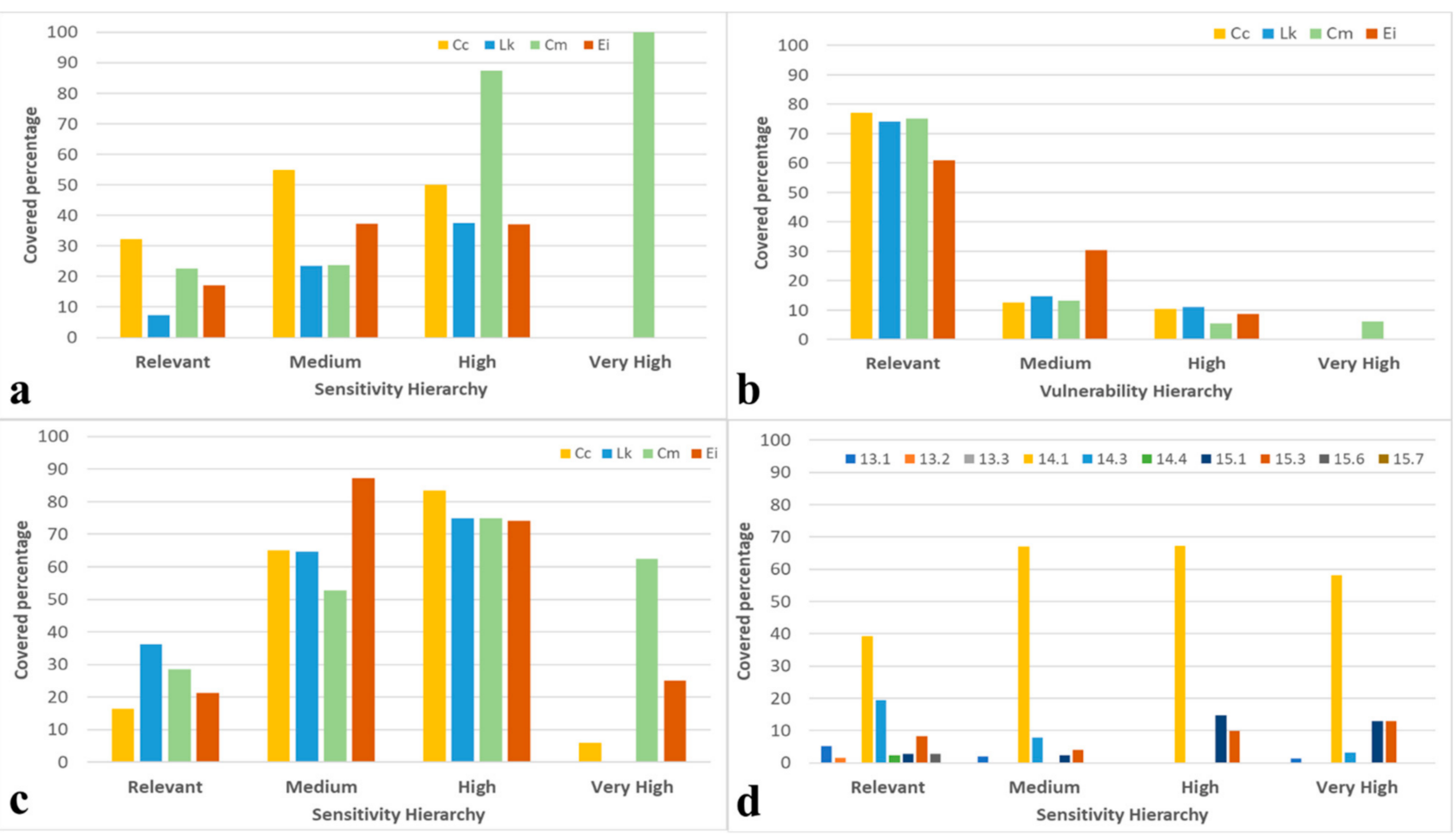

Figure 6. Coverage by territorial administrative tools and spatial regions for the critical habitats of the four marine turtle species (Cc: C. caretta, Lk: L. kempii, Cm: C. mydas, E. imbricata) in the southern Gulf of Mexico. Cover percentage of sensitive (a) and vulnerable (b) areas by natural protected areas and the coverage by priority marine sites (c) for each marine turtle species sensitive category inside level II marine ecoregions in North America (d).

The areas that had medium to very high levels of sensitivity for Kemp's ridley $(20 \% \pm 18.95)$ and hawksbill $(25 \% \pm 21.44)$ turtles were the least protected areas and were mainly distributed inside the Gulf of Mexico. The percentage of sensitive areas encompassed by NPAs was different for each species and sensitivity category (Figure 6a). Areas with medium to high levels of sensitivity for green $(56 \% \pm 45.18)$ and loggerhead turtles (52 \pm 3.54$)$ were mostly covered by NPAs; hawksbills had $37 \%( \pm 0.13)$ of their sensitive areas encompassed by NPAs, and Kemp's ridley turtles were the least protected $(30 \% \pm 9.88)$. In terms of vulnerable areas protected by NPAs, less than $10 \%$ of green turtle very high vulnerability areas are inside NPAs and no other species has this protection (Figure 6b), while close to the same percentage of highly vulnerable areas for loggerhead, Kemp's ridley, and hawksbill turtles were protected by the NPAs.

Territorial prioritization is a management strategy for better allocation of resource investments, and the highly sensitive and vulnerable areas delimited herein are expected to harbor particularly high biodiversity configurations (at distinct levels). Thus, as an umbrella species, the areas occupied by marine turtles are of high relevance. Only 33\% $( \pm 4.73)$ of the sensitive areas of the four species combined occurred inside priority marine sites (PMSs) (Figure 6c). As occurred with NPAs, close to 65\% of the very highly sensitive areas for green turtles was included in PMSs, while only $25 \%$ of this area for hawksbills was included in PMSs. Because PMSs (Figure S2b) have a wider territorial coastal and oceanic cover, areas with high and medium levels of sensitivity for marine turtles are better covered by this management tool. PMSs encompassed the greatest percentage of loggerhead highly sensitive areas (83\%), followed by that of Kemp's ridley, green, and hawksbill turtles (all with a mean $=77 \% \pm 4.34$ covered) (Figure $6 \mathrm{c}$ ). Finally, regarding the areas with medium 
sensitivity levels, PMSs covered more than half of the designated area for this category (mean $=67.43 \% \pm 14.38)$, with hawksbills as the most represented species.

PMSs \#63 (coastal wetlands and Tabasco continental shelf, very important) and \#64 (Laguna de Terminos, very important) harbored the most highly sensitive areas for loggerhead turtles in the southern Gulf of Mexico, while the small PMS \#55 (coastal wetlands and Tuxpan reef, important) and PMS \#56 (Tecolutla River wetlands and Negro Bank, important) in northern Veracruz harbored the most highly sensitive areas for Kemp's ridley turtles; PMSs \#64, \#66 (Dzilam continental shelf, very important), and \#68 (coastal wetlands and Cabo Catoche continental shelf, extremely important) on the western and northern coasts of the Yucatan Peninsula harbored significant sensitive areas for hawksbills, and PMSs \#69 (Contoy Island, very important), \#70 (Chacmochuk lagoon, La Cadena reef, important), \#71 (Makax lagoon, very important), \#72 (Nichupte lagoon system, important), and \#102 (northwestern Caribbean submarine mounts, important) at the northeastern corner of the peninsula harbored the most highly sensitive areas for green turtles. These zones have particularly high relevance for marine biota conservation and recovery.

Another management tool is the ecoregional configuration of marine ecosystems in North America (Figure S2c). Three of the level II marine ecoregions (14.1, 15.1, and 15.3) harbored $84 \%$ of the most sensitive marine turtle areas and $24.59 \%$ of the second most sensitive marine turtle areas (Figure $6 \mathrm{~d}$ ).

Finally, regarding the RMEOP (Figure S2d), only two environmental management units (EMU \#166, on the coast of Tabasco, and \#172, Contoy region) harbored $34 \%$ of the most sensitive areas for the four combined marine turtle species, while a second EMU group (\#171, northern Yucatan; \#187, Campeche Bay; \#188, Campeche escarpment; \#189, Campeche Bank; \#191, Yucatan shelf; \#192 and \#193, Yucatan Current) harbored another $25 \%$ of the same category (Figure S2d; Table S1). The highest cover proportion per EMU of the second most sensitive areas was allocated to different units, with \#178 (central Mexican Caribbean) harboring 28\% of the most sensitive areas and a set of three EMUs (\#160 and \#161, northern Veracruz; \#167 coastal Campeche Bank) harboring 47\% of the areas in this same sensitivity category.

There are specific actions implemented in each of these EMUs, and in these cases, they are associated with six distinct themes: protecting and conserving the ecosystem (38\%), monitoring hydrocarbon pollution (8\%), preserving and exploiting physical oceanographic features $(15 \%)$, managing fisheries $(23 \%)$, managing spills, and balancing tourism and conservation actions ( $8 \%$, each) (Table S1).

\section{Discussion}

The Mexican waters of the Gulf of Mexico are known to harbor critical and sensitive habitats for the four marine turtle species described in this study [44,54,63]. At the same time, marine turtles are known to occur in the northern and southern Gulf of Mexico, necessitating common multinational coordinated actions among the US, Cuba, and Mexico for their protection and recovery.

Satellite telemetry has undoubtedly accelerated the acquisition of ecological data that has expanded the frontiers of knowledge in terms of migratory species, and after decades of its wide use, the acquired data are being more frequently translated to specific management and restoration actions [64].

\subsection{Marine Turtle Ecological Vulnerability}

In addition to evaluating the home range area used by marine megavertebrates, identifying their high potential impact and most vulnerable areas contribute the most to addressing the information gaps related to implementing specific management actions [65].

In our results, the Mexican Caribbean has practically no substantial vulnerable areas. This condition occurs because the ecological vulnerability equation (Appendix A, Equation (A4)) includes a stability coefficient that accounts, in this case, for all the NPAs in this region. Given that all the Mexican Caribbean is inside an NPA (the largest one is named 
the Mexican Caribbean Biosphere Reserve, and together with 13 other NPAs protect up to $>140 \mathrm{~km}$ from shore) and these strategies are supposed to control fishing efforts, which had the highest weighting value in the threats set we evaluated in the current study, the cumulative effect of all NPAs in this region diminishes the vulnerable values in comparison with the remainder of the study area where fishing effort occurs without any NPA at least mitigating or giving the legal context for binding actions. This scenario does not mean that there are no impacts on marine turtles occurring in this region, but that the relative vulnerability is lower in comparison to adjacent areas. The potential impact quantifications do not include the stability coefficient (NPAs) in its equation (Equation (A3)), presenting a description of the impact on marine turtles occurring in the Mexican Caribbean.

As in other studies, the potential bycatch impact caused by high fishing effort has been recognized for these four species in the southern Gulf of Mexico [66-68]. One of the major challenges to diminishing this threat is compliance with the existing laws in several countries. In Mexico, the official Mexican regulation NOM-029-PESC-2006 establishes specifications for the sustainable and responsible capture of rays and sharks in Mexican waters [69]. The gillnets used in this fishery are one of the most dangerous fishing gears for marine turtles, and this Mexican norm specifies that setting any gillnets for rays and sharks inside a 5-km boundary of waters adjacent to marine turtle nesting beaches is forbidden. Surveying all the Mexican littoral zones to verify compliance with this law is a large and an almost impossible task; however, the spatially explicit information provided by this study highlights the areas where the highest potential interactions with marine turtles may occur, and this information is expected to help better prioritize personnel and resources to address this threat.

Likewise, the shrimp fishery is also identified as a particularly dangerous anthropic activity for marine turtles [70,71], and Mexico has official Mexican regulations that establish the specifications for implementing turtle excluder devices ([72,73]). Determining compliance with these laws also benefits from spatially explicit information about where the highest potential interactions with marine turtles could be expected. Furthermore, as Raborn et al. [74] and Willems et al. [75] showed, the use of turtle excluder devices (TED) for addressing sea turtle bycatch in shrimp fisheries has also had benefits for some species of sharks and rays, showing an umbrella effect of marine turtle conservation and restoration efforts on ocean ecosystems. Based on this information, some of the areas with the highest interactions of fishing effort with marine turtles occur in areas near some of the major Mexican ports (e.g., Tuxpan and Veracruz, in Veracruz).

With fishing regulations that decrease marine turtle bycatch in Mexican waters not being observed, the U.S. has put in place economic embargos on Mexico [76]. In response, surveillance efforts have been implemented [77], and locating high potential interaction areas for these species is a great benefit in terms of the socioenvironment.

The potential impact of the oil industry on marine turtles and their habitats is of the highest priorities and must be addressed with the best available information to conduct emergency responses and environmental impact assessments. Yaghmour [78] and Wallace et al. [25] recently described the main potential consequences of oil spills for marine turtles and briefly described some national strategies to address such potential consequences. In Mexico, the National Contingency Plan for Hydrocarbons and Potentially Dangerous Harmful Substance Spills in the Mexican Marine Zones [79] specifies the actions that must be implemented in the case of hydrocarbon spills. One of the main tools for being better prepared is spatially explicit information about the most sensitive areas for endangered species and those areas with the highest potential impact from these anthropic activities [80].

The relevance of spatially explicit information to provide the best preparedness level to address and decrease impacts on marine ecosystems by these anthropic activities has been widely acknowledged [80,81]. Liceaga-Correa et al. [43], García-Aguilar et al. [82], and Sosa-Nishizaki [83] presented potential interactions between marine megavertebrates and oil spill scenarios in the southern and western Gulf of Mexico, and together with McDonald et al. [84], Takeshita et al. [85], and Wallace et al. [86], a spatially explicit heritage has been 
published that provides better information for decision-making on sustainable extractive activities in this ocean region. Integration analyses across research approaches and along in the Gulf of Mexico are needed in the near future to spatially provide outputs.

Finally, the definition of the multispecies vulnerable areas that we present here complements the areas identified by Love et al. [66], Hart et al. [67], Cuevas et al. [20], and Iverson et al. [55]. This definition also contributes substantial and strategic information for preparing for contingency events such as oil spills and providing decision-makers with tools for planning response strategies. Implementing territorial management strategies for vulnerable areas would be expected to have a strong positive impact on the associated ecosystems while promoting the conservation of key marine species. Nevertheless, the implementation of these strategies must be analyzed, including the perspectives and resource needs of local communities to balance marine conservation and marine resources extraction [87-91], particularly with a strong sense of equity for the sustainable use of marine resources and in light of international commitments such as Aichi targets [92].

\subsection{Territorial Administration Implications for Marine Biota}

Under this need to balance marine conservation, restoration, and resource exploitation, territorial ordinances and administration are key tools for accomplishing consensus-driven management scenarios [41,42].

Assessing the effectiveness of natural protected areas (NPAs) for the protection of marine turtles and the ecosystems associated with them has been extensively attended [93-99]. Some of the most sensitive foraging and residency areas for Kemp's ridley (northwestern Yucatan) and loggerhead turtles (offshore Tabasco) were the least protected by existing NPAs in the southern Gulf of Mexico. A similar pattern has been reported for post-nesting hawksbills in the Dominican Republic and Brazil, where less than $25 \%$ of their high-intensity occupancy areas are outside an NPA $[92,98,99]$. This pattern may be explained by the preferences of marine turtles in the current study for occupying areas further than $15 \mathrm{~km}$ from shore, exceeding the usual coverage area of most natural protected areas targeted to protect mainly coastal ecosystems in the southern Gulf of Mexico. The largest NPA, the Mexican Caribbean Biosphere Reserve (decreed in 2016), demands extraordinary resources for law enforcement to effectively accomplish its objectives, and future effectiveness assessments will drive adaptive management efforts for this region.

In the remainder of the southern Gulf of Mexico, there are only seven NPAs, covering less than $8000 \mathrm{~km}^{2}$, which represent one-eighth of the total marine protected surface in the Mexican Caribbean. This disproportionate amount directly influences their effectiveness in protecting key ecosystems and national priority species. These NPAs have distinct categories according to the General Law of Ecological Equilibrium and Environmental Protection (LGEEPA, in Spanish [100]), but all of the NPAs include zones of restricted use and public use.

The designation of an NPA is not enough for sustainable management of biodiversity, including protection and restoration of endangered species; the NPAs must be enforced, and they only occupy a small fraction of the territorial sea in Mexico. As Hillborn and Sinclair [41] suggested, the areas outside NPAs are the areas with the largest need for more intense management interventions to protect marine biodiversity. In southern Gulf of Mexico, most of the critical habitats where half of the marine turtle species are established and indicator key marine ecosystems exist are outside any NPA, increasing the conservation and management uncertainty for all the species.

As Wabnitz et al. [14] described, marine turtles are part of the intricate food webs in the ecosystems they inhabit, and the priority marine sites (PMSs) were designed taking into account several focal species occurring within their boundaries, including the contextual threats for the flora and fauna. The wide spatial intersection between these priority sites and the most sensitive and vulnerable areas for marine turtles suggest a direct association between these key species and high marine biodiversity hotspots. Similarly, the intersection of more than $80 \%$ of the most sensitive sea turtle areas by three level II ecoregions by [60] 
also proves that marine turtles frequently establish their feeding and long-term residency areas in highly biodiverse regions. Spatially explicit outputs such as those presented in the current study contribute to improving downscaled polygons of high interest inside these ecoregions and can guide local actions for biodiversity protection and restoration.

As Hays et al. [15] and Gradzens et al. [16] expanded the knowledge on seagrass distribution and high conservation value areas based on the aggregation areas of the megaherbivores green turtles and dugong, the geographic scope of marine turtles may be used as an indicator of where key marine ecosystems are distributed. These species act as sentinel and umbrella species, and as they attract management and protection focus more readily than other noncharismatic species, they benefit other species that occupy the same habitats, such as seagrasses, coral reefs, and species in riverine deltas. Some activities in the National Action Programs for Conservation (PACEs) of marine turtle species in Mexico, which are similar to national recovery plans, include studying and conserving the flora and fauna associated with marine turtles, as well as promoting sustainable and conservation-compatible economic activities for local communities in areas associated with critical habitats for marine turtles. These conditions are suggested to be part of the marine turtle umbrella effect, and they should be used more often for integral ecosystem management and restoration.

Finally, the Regional Marine Ecological Ordering Program of the Gulf of Mexico and Mexican Caribbean (RMEOP) includes actions for regulating the ocean territory to balance marine biodiversity conservation, renewable energy sources, fisheries, and tourism actions. While the established actions are pertinent, current, and strategic, they need to be upgraded to binding regulations, such as those of an NPA; otherwise, in Mexico, these actions are abolishable unilaterally by an interested government sector. In southeastern Mexico, this scenario has occurred along the Yucatan and Quintana Roo (Mexico) coasts, where ecological and territorial orders specify sea turtle protection actions, but they are not properly enforced, as they are not binding [101-104], facilitating the occurrence of threats in highly ecological sensitive areas in southern Gulf of Mexico. Nevertheless, experiences in other regions have shown that territorial ordinances have positive impacts on biodiversity conservation $[42,105]$; therefore, we encourage the continued creation and updating of these instruments in the Mexican Atlantic littoral zone for integrated ecosystem conservation and recovery.

\section{Conclusions}

Distinct approaches for marine territorial ordinance are at their core aiming to balance anthropic activities and ecosystem conservation under a sustainable vision, with human communities as an element of the socioecosystem [3,106-111]. Although we do not mean that any of these approaches is the panacea for solving any socioenvironmental conflict, they have proven to be successful in procuring socioenvironmental equity and facilitating solutions when properly developed.

While the spatially explicit biodiversity outputs that we provide in this study are strategic for planning in balanced socioenvironmental contexts aiming to sustainably conserve the ecological integrity of marine biodiversity through key focal species, the gap between scientific knowledge and public policies in terms of adopting this information still needs to be addressed. The contextual outputs presented in this study have promoted knowledge transfer about the actions managers in the environmental and oil industry in Mexico need to implement to promote the adoption of this information.

Historically, nongovernmental organizations (NGOs) have been strategic allies in translating and providing scientific information from academia to decision-makers, managers, and politicians to promote robust and better informed public policies, particularly in the socioenvironmental realm [112-116]. A needed task is the promotion of forums in which NGOs, academia, local communities, and decision-makers participate, where this spatially explicit information is presented to obtain its adoption in consensus-driven management 
strategies that promote sustainable habitats and use of the Mexican Sea, securing long-term viability of the associated socioecosystems.

Conversely, while the scientific community still needs to work to improve their strategies and skills related to transmitting scientific information [117], decision-makers and policy-makers also have a window of opportunity for better approaching scientists and NGOs. When bridging this gap, they have access to robust information that contributes to making their job easier and stronger, capitalizing on all the substantial investments that several agencies and governments have made to create the most valuable and needed scientific information. In the end, narrowing this gap between science and environmental policy-making has been the subject of study for decades, and successful cases have shown that it is feasible and desirable [118].

Although these final remarks may seem to be unrelated to the key marine species, the umbrella/surrogate positive effects of territorial regulations that provide legal certainty and the transfer and adoption of this scientific knowledge are crucial to sustainably promoting local communities' well-being and addressing their constitutional right to a healthy environment and access to universal knowledge.

Supplementary Materials: The following supporting information can be downloaded at: https:// www.mdpi.com/article/10.3390/su14010184/s1, Figure S1: Spatial configuration of the cumulative ecological vulnerability for hawksbill (a), green (b), Kemp's ridley (c) and loggerhead (d) individuals and their habitats in the southern and western Gulf of Mexico., Figure S2: Territorial management tools for Mexican waters, including (a) binding tools (natural protected areas and oil industry safeguards), (b) ecologically relevant sites (priority marine sites, PMS), (c) North American marine ecoregions (Level II, NAEL2), and (d) the Mexican Regional Marine Ecological Ordering Program of the Gulf of Mexico and Mexican Caribbean, Table S1: Specific management actions established by the Regional Marine Ecological Ordering Program of the Gulf of Mexico and Mexican Caribbean to be implemented in each environmental management unit (EMU).

Author Contributions: Conceptualization, resources, writing-review and editing, A.U.-M., M.d.l.A.L.-C. and E.C.; methodology, validation, formal analysis, investigation, data curation, writing — original draft preparation, A.U.-M. and E.C.; software, visualization, A.U.-M.; project administration, funding acquisition, M.d.l.A.L.-C. and E.C. All authors have read and agreed to the published version of the manuscript.

Funding: This research was funded by the Mexican National Council for Science and TechnologyMexican Ministry of Energy-Hydrocarbon Fund, project 201441. This is a contribution of the Gulf of Mexico Research Consortium (CIGoM). We acknowledge PEMEX's specific request to the Hydrocarbon Fund to address the environmental effects of oil spills in the Gulf of Mexico, and the funding source did not participate in the design of this assessment.

Institutional Review Board Statement: The satellite tracking was conducted according to the Mexican Environmental law under federal permit numbers SGPA/DGVS/09583/15, SGPA/DGVS/06438/17, SGPA/DGVS/03989/17, and SATI/PC/016/16.

Informed Consent Statement: Not applicable.

Data Availability Statement: Some of the datasets presented in this article are not readily available because of restrictions by funding sources. Requests to access the datasets should be directed to M.d.l.A.L.-C. and E.C.

Acknowledgments: We would like to thank the project team who contributed to marine turtle tagging: S. Gallegos-Fernández, P.A. García-Alvarado, G. Mexicano-Cíntora, A.G. Ortíz-Méndez, D. Espinoza-Puch, E.B. Palafox-Juárez, H. Hernández-Núñez, E.R. Castro-Pineda, V. GuzmánHernández, and R.J. González-Díaz-Mirón. Additionally, we would like to thank the students who participated in the subproject: R.A. Maldonado-Bandala, K. Coronel-Almeyda, and D.A. Celis-Padilla. We would like to thank the following institutions and organizations because their support in administrative and field work to make the female turtle tracking possible: National Commission of Natural Protected Areas that facilitated the field work through the directors of their regional offices (Planicie Costera y Golfo de México, Península de Yucatán), as well as the directors and staff of the following natural protected areas: APFF Laguna Madre y Delta del Río Bravo, Santuario Playa de Rancho Nuevo, PN Sistema Arrecifal Veracruzano, APFF Sistema Arrecifal Lobos-Tuxpan, RB Los Tuxtlas, 
APFF Laguna de Términos, RB Los Petenes, RB Ría Celestún, PN Arrecife Alacranes, RB Ría Lagartos, Santuario Playa Río Lagartos, PN Isla Contoy, APFF Yum Balam, RB Caribe Mexicano, PN Arrecifes de Puerto Morelos, PN Tulum, PN Arrecifes de Cozumel, and APFF Isla de Cozumel. Additionally, we thank the public and private institutions in charge of biological monitoring of sea turtle nesting who contributed and facilitated the turtle tagging and some staff of the former institutions who also collaborated in turtle tagging: Acuario de Veracruz, Vida Milenaria, Comisión Federal de Electricidad, Universidad Veracruzana, Desarrollo sustentable, Grupo Tortuguero de la Laguna, Universidad Autónoma del Carmen, Universidad Autónoma de Campeche, Quelonios, Estación de Investigación Oceanográfica del Carmen, $7^{\mathrm{a}}$ y $9^{\mathrm{a}}$ Zonas Navales de la Secretaría de Marina Armada de México, SEMABICC-Gobierno de Campeche, Fileteras del Petén, Pronatura Península de Yucatán, CETMAR No. 17 Progreso, SEDUMA-Gobierno de Yucatán, Fundación Palace, Dorado Royale, H. Municipio de Solidaridad, Hotel Paradisus, Fundación de Parques y Musesos de Cozumel Quintana Roo, Karisma, Centro Ecológico Akumal, Fundación Bahía Príncipe, H. Ayuntamiento de Tulum, Flora, Fauna y Cultura de México, and Parque Xcaret.

Conflicts of Interest: The authors declare no conflict of interest. The funders had no role in the design of the study; in the collection, analyses, or interpretation of data; in the writing of the manuscript, or in the decision to publish the results.

\section{Appendix A}

The ecological vulnerability of an object of interest, in this case the marine turtle populations, to a specific threat $\left(\operatorname{Vuln}_{T h}\right)$ is expressed in mathematical terms as:

$$
V u l n_{T h}=S e n s * E x p_{T h}-S C
$$

where $V u l n_{T h}$ is equal to its sensitivity (Sens) multiplied by its exposure (Exp) to a specific threat, minus the stability coefficient (SC) of the object of interest, in our case marine turtle populations (taken from [20]).

In this context, we adopted the definition of sensitivity as the degree to which the essential attributes of the object of interest (OI) are impacted by a specific threat [119]. As Cuevas et al. [20] did, we evaluated sensitivity as the ecologically inverse relationship with the viability of the marine turtle populations, numerically expressed as:

$$
\text { Sens }=\sum_{i} \lambda_{i} A t t_{i}
$$

where $\lambda_{i}$ refers to the relative weight of the ecological attribute $i\left(A t t_{i}\right)$ of the marine turtle populations. Each of the three distinct stages referred to in the Methods Section (see Section 2.2) (internesting, migrating, and feeding) became an indicator of attributes for the sensitivity evaluation of each species, and they were combined into a final single sensitive index.

The exposure, the second term in Equation (A1), quantifies the occurrence of a threat negatively impacting the marine turtle populations. The intensity of the interaction between sensitivity and any threat was termed potential impact $(P I)$ :

$$
P I_{T h}=\operatorname{Sens} * \operatorname{Exp}_{T h}
$$

where Sens is the sensitivity obtained in Equation (A2), and $\operatorname{Exp}_{T h}$ is exposure as explained above. The PI was described for six different in-water threats to marine turtles, and the subsequent sections are explained.

Finally, we followed Cuevas et al. [20] and we integrated the set of conditions previously documented to contribute to the stability of each species when facing natural and anthropic threats, and their assigned value was subtracted from the potential impact account.

As in Cuevas et al. [20], to maintain mathematical consistency in the calculations, all the variables were rescaled from 0 to 1 when summed in all equations and when the terms interacted in the general equation, including the definition of numerical classes for each assessed variable [120]. 
Considering the exposition of the marine turtle populations to $m$ threats, the accumulated vulnerability is then defined as the sum of its vulnerabilities to each weighted threat:

$$
\text { Cum. Vuln } \mathrm{OI}=\sum_{j=1}^{m} u_{j} * V u \ln T h_{j}
$$

where $V u \ln T h_{j}$ is the ecological vulnerability of the object of interest to the threat $j$ (already defined using Equation (A1)), and $\mu_{j}$ is the weight assigned to the specific threat $j$ [20].

Finally, when the combined ecological vulnerability of the species to the distinct assessed threats is determined, the total cumulative vulnerability for the group of marine turtle populations was calculated using Equation (A5):

$$
\text { Total Cum. Vuln. }=\sum_{i=1}^{n} \gamma_{i} * \text { Ac.VulnOI }
$$

where $\gamma$ is the weight assigned to the marine turtle population $(O I)$ based on its relative conservation status among the evaluated species.

We solved all these equations using map algebra in the QGIS program for each hexagon in a lattice and obtained the spatial configuration of ecological vulnerability for each of the four marine turtle species and their combined expression.

Ecological attributes

Each term of the vulnerability equation was built using variables derived from the satellite tracked dataset, as well as from public geographic data. As with Cuevas et al. [20], the sensitivity was built from the combination of three indicators derived from the geographic locations of post-nesting females: (1) aggregation of in-water reproductive females (internesting habitats), (2) feeding/residency, and (3) spatial connectivity between critical habitats (migratory corridors), which were also weighted and integrated into the first parameter of Equation (A1). All the variables were transferred to a hexagonal lattice composed of 25-km diameter hexagons, which were considered the minimum spatial analysis unit.

In order to obtain the sensitivity index, kernel utilization distributions (KUDs) were calculated for every satellite tracked individual during their internesting (reproductive aggregation) and feeding (residency) movement stages, using a spatial resolution of $1 \mathrm{~km}$ and a smoothing factor $(\mathrm{h})$ calculated with the ad hoc method [121,122], and home ranges were delineated from the $80 \%$ isopleth of each KUD [123]. Individual delineated home ranges were merged for each type of aggregation area to build a single layer that included both foraging and internesting life stages for each marine turtle species.

Spatial connectivity was estimated as the location records density for each individual migration overlaid onto the hexagonal lattice. The density value at each hexagonal spatial analysis unit was rescaled to a value between 0 and 1 .

In the process of calculating ecological vulnerability, we analyzed six different threats reported to jointly act on the four marine turtle species [124,125], impacting their populations and habitats. The studied threats were: fishing effort, occurrence of hurricanes, cargo vessel transit, seismic surveys, impact from oil extraction platforms, and increase in average sea surface temperature. The relative importance and magnitude of the negative impact on marine turtles was taken from Cuevas et al. [20] who quantified them via national experts in terms of their severity, scope, and irreversibility. Based on the hierarchy derived from the expert knowledge reported [20], we assigned the numeric weight to each threat, and those weights were used in the next steps [126,127].

In terms of consistency and comparability, we used the same layers as Cuevas et al. [20] did. For description purposes, we summarize the main features of these layers. Fishing effort was developed into a fishery intensity index that accounted for different weights for each studied fishing gear and vessel size category (acquired from historical data summarized over 10 years from the National Yearbooks of Fisheries in Mexico and the National Fishing Chart $[128,129]$, multiplied by the number of vessels and the mean annual production per fishery $[128,130])$. 
The increase in the average sea surface temperature (SST) is widely recognized as a negative climatic factor for marine turtles [131,132]. At each hexagon, representing a spatial analysis unit, we assessed and represented the SST trend (the slope of a linear model) in that polygon for the period 2003 to 2016 . The SST data were derived from MODIS satellite imagery [133].

Furthermore, the occurrence of hurricanes has been reported as one of the issues of concern for marine turtle populations and their habitats [134,135]. We built a tropical hurricane impacting index using the tracks of tropical storms and hurricanes from 1851 to 2016 [136,137], which were weighted according to the Saffir-Simpson scale and included a decay buffer for the trajectories of the storms with $10 \mathrm{~km}$ steps up to $40 \mathrm{~km}$ [135]. A rescaled sum ( 0 to 1 ) of all intersecting buffer polygons in hexagons was calculated to obtain an indicator layer for this threat.

Cargo vessel transit was also considered a potential source of perturbation to turtle migration routes and reproductive aggregations, in addition to direct turtle strikes. This layer was built by estimating the vessel densities from data on cargo vessel locations in the southern Gulf of Mexico. The dataset was acquired from the Department of Commerce through NOAA's Office for Coastal Management for 2011 and 2013 [138].

The last two threats are linked to the oil extraction industry, which is of particular interest for marine turtle recovery and conservation in the Gulf of Mexico, as it is one of the most severe threats to in-water habitats and populations in this same region. The layer we built represents an indicator of the threat to marine turtles within $30 \mathrm{~km}$ buffers around the locations of hydrocarbon extraction platforms in the study area (556 platforms) [139], together with oil extraction fields designated by the Mexican Government from the Mexican National Hydrocarbons Commission [140]. The indicator differentiated weights for the platforms (active or standby) and the class of each field (for offer, contracted or planned).

Another threat of high concern associated to the oil industry is the seismic surveys [141]. We built a layer using polygons of where seismic surveys had been reported, and those polygons were weighted based on the assumed negative impact that different survey technologies that were used have on the ecosystem (air guns for two- and three-dimensional (2D and 3D) studies or magnetism) [142].

Finally, consistently with Cuevas et al. [20] we used their published set of stability indicators for completing the general vulnerability quantification for all species to multiple threats, including natural protected areas, no-take marine reserves, population size trend, and safeguards. This term was defined as the intrinsic or extrinsic conditions of the OI that promoted a tendency to attain or maintain certain suitable conditions for survival and development [20].

These indicators were quantitatively integrated into the hexagonal lattice for the study area. The layers included [20] a total of 19 natural protected areas (NPAs) in different conservation categories, classified according to the level of restriction [100]; safeguard areas, where any oil exploration or exploitation activity is forbidden, decreed by the Mexican government around coral reefs and rocky reefs in the Bank of Campeche and the Mexican Caribbean [143]; and the regional trends in the sea turtle population attributed as a mean indicator value for the linked feeding/residency aggregation areas, attributing a higher stability coefficient value to those nesting grounds with positive nesting trends [20].

\section{References}

1. Moberg, F.; Rönnbäck, P. Ecosystem Services of the Tropical Seascape: Interactions, Substitutions and Restoration. Ocean Coast. Manag. 2003, 46, 27-46. [CrossRef]

2. Guannel, G.; Arkema, K.; Ruggiero, P.; Verutes, G. The Power of Three: Coral Reefs, Seagrasses and Mangroves Protect Coastal Regions and Increase Their Resilience. PLoS ONE 2016, 11, e0158094. [CrossRef]

3. Challenger, A.; Cordova, A.; Lazos Chavero, E.; Equihua, M.; Maass, M. Opportunities and Obstacles to Socioecosystem-Based Environmental Policy in Mexico: Expert Opinion at the Science-Policy Interface. Ecol. Soc. 2018, 23, art31. [CrossRef]

4. García-Jácome, L.G.; García-Frapolli, E.; Bonilla-Moheno, M.; Rangel-Rivera, C.E.; Benítez, M.; Ramos-Fernández, G. Multiple Resource Use Strategies and Resilience of a Socio-Ecosystem in a Natural Protected Area in the Yucatan Peninsula, Mexico. Front. Sustain. Food Syst. 2020, 4, 522657. [CrossRef] 
5. Timpane-Padgham, B.L.; Beechie, T.; Klinger, T. A Systematic Review of Ecological Attributes that Confer Resilience to Climate Change in Environmental Restoration. PLoS ONE 2017, 12, e0173812. [CrossRef]

6. Bouchard, S.S.; Bjorndal, K.A. Sea Turtles as Biological Transporters of Nutrients and Energy from Marine to Terrestrial Ecosystems. Ecology 2000, 81, 2305-2313. [CrossRef]

7. Bjorndal, K.A.; Jackson, J.B.C. Roles of sea turtles in marine ecosystems: Reconstructing the past. In The Biology of Sea Turtles; CRC Press: Boca Raton, FL, USA, 2003; Volume II.

8. Friedman, W.R.; Halpern, B.S.; McLeod, E.; Beck, M.W.; Duarte, C.M.; Kappel, C.V.; Levine, A.; Sluka, R.D.; Adler, S.; O'Hara, C.C.; et al. Research Priorities for Achieving Healthy Marine Ecosystems and Human Communities in a Changing Climate. Front. Mar. Sci. 2020, 7, 5. [CrossRef]

9. Hammerschlag, N.; Schmitz, O.J.; Flecker, A.S.; Lafferty, K.D.; Sih, A.; Atwood, T.B.; Gallagher, A.J.; Irschick, D.J.; Skubel, R.; Cooke, S.J. Ecosystem Function and Services of Aquatic Predators in the Anthropocene. Trends Ecol. Evol. 2019, 34, 369-383. [CrossRef] [PubMed]

10. De Lange, H.J.; Sala, S.; Vighi, M.; Faber, J.H. Ecological Vulnerability in Risk Assessment-A Review and Perspectives. Sci. Total Environ. 2010, 408, 3871-3879. [CrossRef] [PubMed]

11. Hazen, E.L.; Abrahms, B.; Brodie, S.; Carroll, G.; Jacox, M.G.; Savoca, M.S.; Scales, K.L.; Sydeman, W.J.; Bograd, S.J. Marine Top Predators as Climate and Ecosystem Sentinels. Front. Ecol. Environ. 2019, 17, 565-574. [CrossRef]

12. Caro, T.M.; O'Doherty, G. On the Use of Surrogate Species in Conservation Biology. Conserv. Biol. 1999, 13, 805-814. [CrossRef]

13. Hunter, M.; Westgate, M.; Barton, P.; Calhoun, A.; Pierson, J.; Tulloch, A.; Beger, M.; Branquinho, C.; Caro, T.; Gross, J.; et al. Two Roles for Ecological Surrogacy: Indicator Surrogates and Management Surrogates. Ecol. Indic. 2016, 63, 121-125. [CrossRef]

14. Wabnitz, C.; Balazs, G.; Beavers, S.; Bjorndal, K.; Bolten, A.; Christensen, V.; Hargrove, S.; Pauly, D. Ecosystem Structure and Processes at Kaloko Honokohau, Focusing on the Role of Herbivores, Including the Green Sea Turtle Chelonia mydas, in Reef Resilience. Mar. Ecol. Prog. Ser. 2010, 420, 27-44. [CrossRef]

15. Hays, G.C.; Alcoverro, T.; Christianen, M.J.A.; Duarte, C.M.; Hamann, M.; Macreadie, P.I.; Marsh, H.D.; Rasheed, M.A.; Thums, M.; Unsworth, R.K.F.; et al. New Tools to Identify the Location of Seagrass Meadows: Marine Grazers as Habitat Indicators. Front. Mar. Sci. 2018, 5, 9. [CrossRef]

16. Gradzens, C.; Marsh, H.; Fuentes, M.M.P.B.; Limpus, C.J.; Shimada, T.; Hamann, M. Satellite tracking of sympatric marine megafauna can inform the biological basis for species co-management. PLoS ONE 2014, e98944. [CrossRef]

17. Zacharias, M.A.; Roff, J.C. A Hierarchical Ecological Approach to Conserving Marine Biodiversity. Conserv. Biol. 2000, 14, 1327-1334. [CrossRef]

18. Halpern, B.S.; Walbridge, S.; Selkoe, K.A.; Kappel, C.V.; Micheli, F.; D’Agrosa, C.; Bruno, J.F.; Casey, K.S.; Ebert, C.; Fox, H.E.; et al. A Global Map of Human Impact on Marine Ecosystems. Science 2008, 319, 948-952. [CrossRef]

19. Maxwell, S.M.; Hazen, E.L.; Bograd, S.J.; Halpern, B.S.; Breed, G.A.; Nickel, B.; Teutschel, N.M.; Crowder, L.B.; Benson, S.; Dutton, P.H.; et al. Cumulative Human Impacts on Marine Predators. Nat. Commun. 2013, 4, 2688. [CrossRef]

20. Cuevas, E.; Liceaga-Correa, M.; Uribe-Martínez, A. Ecological Vulnerability of Two Sea Turtle Species in the Gulf of Mexico: An Integrated Spatial Approach. Endanger. Species Res. 2019, 40, 337-356. [CrossRef]

21. Ramos, R.; González-Solís, J. Trace Me If You Can: The Use of Intrinsic Biogeochemical Markers in Marine Top Predators. Front. Ecol. Environ. 2012, 10, 258-266. [CrossRef]

22. Cuevas, E. Dimensiones espacial y temporal de los procesos de selección de hábitats críticos por las tortugas marinas. Rev. Biol. Mar. Oceanogr. 2017, 52, 187-199. [CrossRef]

23. Frazier, J. Marine Turtles: The Role of Flagship Species in Interactions between People and the Sea. Mast 2005, 3, 5-38.

24. Kalinkat, G.; Cabral, J.S.; Darwall, W.; Ficetola, G.F.; Fisher, J.L.; Giling, D.P.; Gosselin, M.-P.; Grossart, H.-P.; Jähnig, S.C.; Jeschke, J.M.; et al. Flagship Umbrella Species Needed for the Conservation of Overlooked Aquatic Biodiversity: Freshwater Flagship Umbrella Species. Conserv. Biol. 2017, 31, 481-485. [CrossRef]

25. Wallace, B.; Stacy, B.; Cuevas, E.; Holyoake, C.; Lara, P.; Marcondes, A.; Miller, J.; Nijkamp, H.; Pilcher, N.; Robinson, I.; et al. Oil Spills and Sea Turtles: Documented Effects and Considerations for Response and Assessment Efforts. Endanger. Species Res. 2020, 41, 17-37. [CrossRef]

26. Valverde, R.A.; Holzwart, K.R. Sea turtles of the Gulf of Mexico. In Habitats and Biota of the Gulf of Mexico: Before the Deepwater Horizon Oil Spill; Springer: New York, NY, USA, 2017; pp. 1189-1351.

27. McConkey, K.R.; O’Farrill, G. Cryptic Function Loss in Animal Populations. Trends Ecol. Evol. 2015, 30, 182-189. [CrossRef] [PubMed]

28. Bolten, A.B.; Crowder, L.B.; Dodd, M.G.; MacPherson, S.L.; Musick, J.A.; Schroeder, B.A.; Witherington, B.E.; Long, K.J.; Snover, M.L. Quantifying Multiple Threats to Endangered Species: An Example from Loggerhead Sea Turtles. Front. Ecol. Environ. 2011, 9, 295-301. [CrossRef]

29. Lovich, J.E.; Ennen, J.R.; Agha, M.; Gibbons, J.W. Where Have All the Turtles Gone, and Why Does It Matter? BioScience 2018, 68, 771-781. [CrossRef]

30. Tisdell, C.; Wilson, C. Ecotourism for the survival of sea turtles and other wildlife. Biodivers. Conserv. 2002, 11, 1521-1538 [CrossRef] 
31. Richardson, K.L.; Gold-Bouchot, G.; Schlenk, D. The Characterization of Cytosolic Glutathione Transferase from Four Species of Sea Turtles: Loggerhead (Caretta Caretta), Green (Chelonia Mydas), Olive Ridley (Lepidochelys Olivacea), and Hawksbill (Eretmochelys imbricata). Comp. Biochem. Physiol. Part C Toxicol. Pharmacol. 2009, 150, 279-284. [CrossRef]

32. Jackson, J.B.C. Reefs since Columbus. Coral Reefs 1997, 16, S23-S32. [CrossRef]

33. Goatley, C.H.R.; Hoey, A.S.; Bellwood, D.R. The Role of Turtles as Coral Reef Macroherbivores. PLoS ONE 2012,7 , e39979. [CrossRef] [PubMed]

34. Richardson, A.J.; Bakun, A.; Hays, G.C.; Gibbons, M.J. The jellyfish joyride: Causes, consequences and management responses to a more gelatinous future. Trends Ecol. Evol. 2009, 24, 312-322. [CrossRef] [PubMed]

35. Arai, M.N. Predation on pelagic coelenterates: A review. J. Mar. Biol. Assoc. UK 2005, 85, 523-536. [CrossRef]

36. Johnson, R.A.; Gulick, A.G.; Bolten, A.B.; Bjorndal, K.A. Blue Carbon Stores in Tropical Seagrass Meadows Maintained under Green Turtle Grazing. Sci. Rep. 2017, 7, 13545. [CrossRef]

37. Johnson, R.A.; Gulick, A.G.; Constant, N.; Bolten, A.B.; Smulders, F.O.H.; Christianen, M.J.A.; Nava, M.I.; Kolasa, K.; Bjorndal, K.A. Seagrass Ecosystem Metabolic Carbon Capture in Response to Green Turtle Grazing across Caribbean Meadows. J. Ecol. 2020, 108, 1101-1114. [CrossRef]

38. Hannan, L.B.; Roth, J.D.; Ehrhart, L.M.; Weishampel, J.F. Dune Vegetation Fertilization by Nesting Sea Turtles. Ecology 2007, 88 , 1053-1058. [CrossRef]

39. Madden, D.; Ballestero, J.; Calvo, C.; Carlson, R.; Christians, E.; Madden, E. Sea Turtle Nesting as a Process Influencing a Sandy Beach Ecosystem. Biotropica 2008, 40, 758-765. [CrossRef]

40. Vander Zanden, H.B.; Bjorndal, K.A.; Inglett, P.W.; Bolten, A.B. Marine-Derived Nutrients from Green Turtle Nests Subsidize Terrestrial Beach Ecosystems. Biotropica 2012, 44, 294-301. [CrossRef]

41. Hilborn, R.; Sinclair, A.R.E. Biodiversity Protection in the 21st Century Needs Intact Habitat and Protection from Overexploitation Whether inside or Outside Parks. Conserv. Lett. 2021, 14, e12830. [CrossRef]

42. Ware, M.; Fuentes, M. Leave No Trace Ordinances for Coastal Species Management: Influences on Sea Turtle Nesting Success. Endanger. Species Res. 2020, 41, 197-207. [CrossRef]

43. Liceaga-Correa, M.A.; Uribe-Martínez, A.; Cuevas, E. Vulnerabilidad ecológica de tortugas marinas ante múltiples amenazas y derrames de petróleo de gran escala en el golfo de México. In Vulnerabilidad Ecológica del Golfo de México Ante Derrames a Gran Escala; CICESE, CINVESTAV, UNAM: Ensenada, Mexico, 2020; Volume II, pp. 17-41.

44. Uribe-Martínez, A.; Liceaga-Correa, M.; de los, A.; Cuevas, E. Critical In-Water Habitats for Post-Nesting Sea Turtles from the Southern Gulf of Mexico. J. Mar. Sci. Eng. 2021, 9, 793. [CrossRef]

45. Dow Piniak, W.; Eckert, K. Sea Turtle Nesting Habitat in the Wider Caribbean Region. Endanger. Species Res. 2011, 15, 129-141. [CrossRef]

46. Cuevas, E.; Abreu-Grobois, F.; Guzmán-Hernández, V.; Liceaga-Correa, M.; van Dam, R. Post-Nesting Migratory Movements of Hawksbill Turtles Eretmochelys imbricata in Waters Adjacent to the Yucatan Peninsula, Mexico. Endanger. Species Res. 2008, 10, 123-133. [CrossRef]

47. Méndez, D.; Cuevas, E.; Navarro, J.; González-Garza, B.I.; Guzmán-Hernández, V. Rastreo satelital de las hembras de tortuga blanca Chelonia mydas y evaluación de sus ámbitos hogareños en la costa norte de la península de Yucatán, México. Rev. Biol. Mar. Oceanogr. 2013, 48, 497-509. [CrossRef]

48. Vázquez, M.; Cuevas, E. Hábitats críticos de tortuga blanca (Chelonia mydas) y carey (Eretmochelys imbricata) en la península de Yucatán y su coincidencia espacial con zonas de pesca artesanal. In El Uso del Conocimiento de las Tortugas Marinas Como Herramienta Para la Restauración de Sus Poblaciones y Hábitats Asociados en México; Universidad Autónoma del Carmen: Ciudad del Carmen, Mexico, 2019; pp. 57-62.

49. Gallegos-Fernández, S.A.; Cuevas, E.; de los Ángeles Liceaga-Correa, M. Procesos metodológicos para la colocación de transmisores satelitales en tortugas marinas de caparazón duro en playas de anidación. Rev. Biol. Mar. Oceanogr. 2018, 53, 147. [CrossRef]

50. R Core Team. A Language and Environment for Statistical Computing; R Foundation for Statistical Computing: Vienna, Austria, 2019.

51. Lopez, R.; Malardé, J.P.R.; Gaspar, P. Improving Argos doppler location using multiple-model Kalman filtering. IEEE Trans. Geosci. Remote Sens. 2013, 52, 4744-4755. [CrossRef]

52. Boyd, J.D.; Brightsmith, D.J. Error Properties of Argos Satellite Telemetry Locations Using Least Squares and Kalman Filtering PLoS ONE 2013, 8, e63051. [CrossRef]

53. Shaver, D.J.; Hart, K.M.; Fujisaki, I.; Rubio, C.; Sartain, A.R.; Peña, J.; Burchfield, P.M.; Gamez, D.G.; Ortiz, J. Foraging Area Fidelity for Kemp's Ridleys in the Gulf of Mexico. Ecol. Evol. 2013, 3, 2002-2012. [CrossRef]

54. Shaver, D.J.; Hart, K.M.; Fujisaki, I.; Rubio, C.; Sartain-Iverson, A.R.; Peña, J.; Gamez, D.G.; de Jesus Gonzales Diaz Miron, R.; Burchfield, P.M.; Martinez, H.J.; et al. Migratory Corridors of Adult Female Kemp's Ridley Turtles in the Gulf of Mexico. Biol. Conserv. 2016, 194, 158-167. [CrossRef]

55. Iverson, A.R.; Benscoter, A.M.; Fujisaki, I.; Lamont, M.M.; Hart, K.M. Migration Corridors and Threats in the Gulf of Mexico and Florida Straits for Loggerhead Sea Turtles. Front. Mar. Sci. 2020, 7, 208. [CrossRef]

56. Freitas, C.; Lydersen, C.; Fedak, M.A.; Kovacs, K.M. A Simple New Algorithm to Filter Marine Mammal Argos Locations. Mar. Mammal Sci. 2008, 24, 315-325. [CrossRef] 
57. Hart, K.M.; Lamont, M.M.; Iverson, A.R.; Smith, B.J. The Importance of the Northeastern Gulf of Mexico to Foraging Loggerhead Sea Turtles. Front. Mar. Sci. 2020, 7, 330. [CrossRef]

58. Granizo, T.; Molina, M.E.; Secaira, E.; Herrera, B. Manual de Planificación Para la Conservación de Áreas, PCA, 1st ed.; The Nature Conservancy/USAID: Quito, Ecuador, 2006.

59. Zacharias, M.A.; Gregr, E.J. Sensitivity and Vulnerability in Marine Environments: An Approach to Identifying Vulnerable Marine Areas. Conserv. Biol. 2005, 19, 86-97. [CrossRef]

60. Wilkinson, T.; Wiken, E.; Bezaury-Creel, J.; Hourigan, T.; Agardy, T.; Herrmann, H.; Janishevski, L.; Madden, C.; Morgan, L.; Padilla, M. Marine ecoregions of North America. In Geospatial_Data_Presentation_Form: Vector Digital Data; Commission for Environmental Cooperation: Montreal, QC, Canada, 2009.

61. Comisión Nacional para el Conocimiento y Uso de la Biodiversidad; Comisión Nacional de Áreas Naturales Protegidas. The nature conservancy-Programa México; Pronatura. In Sitios Prioritarios Marinos para la Conservación de la Biodiversidad; CONABIO: Ciudad de México, Mexico, 2007.

62. Diario Oficial de la Federación. Acuerdo por el Que Se Expide la Parte Marina del Programa de Ordenamiento Ecológico Marino y Regional del Golfo de México y Mar Caribe y Se da a Conocer la Parte Regional del Propio Programa (Continúa en la Segunda Sección). Available online: http:/ / dof.gob.mx/nota_detalle.php?codigo=5279084\&fecha=24/11/2012 (accessed on 10 October 2021).

63. Hart, K.M.; Lamont, M.M.; Fujisaki, I.; Tucker, A.D.; Carthy, R.R. Common Coastal Foraging Areas for Loggerheads in the Gulf of Mexico: Opportunities for Marine Conservation. Biol. Conserv. 2012, 145, 185-194. [CrossRef]

64. Hays, G.C.; Bailey, H.; Bograd, S.J.; Bowen, W.D.; Campagna, C.; Carmichael, R.H.; Casale, P.; Chiaradia, A.; Costa, D.P.; Cuevas, E.; et al. Translating Marine Animal Tracking Data into Conservation Policy and Management. Trends Ecol. Evol. 2019, 34, 459-473. [CrossRef] [PubMed]

65. Edgar, G.J. Does the Global Network of Marine Protected Areas Provide an Adequate Safety Net for Marine Biodiversity?: EDITORIAL. Aquat. Conserv. Mar. Freshw. Ecosyst. 2011, 21, 313-316. [CrossRef]

66. Love, M.; Robbins, C.; Baldera, A.; Eastman, S.; Bolten, A.; Hardy, R.; Herren, R.; Metz, T.; Zanden, H.B.V.; Wallace, B.; et al Restoration without Borders: An Assessment of Cumulative Stressors to Guide Large-Scale, Integrated Restoration of Sea Turtles in the Gulf of Mexico. Ocean. Conserv. Rep. 2017. [CrossRef]

67. Hart, K.M.; Iverson, A.R.; Fujisaki, I.; Lamont, M.M.; Bucklin, D.; Shaver, D.J. Marine Threats Overlap Key Foraging Habitat for Two Imperiled Sea Turtle Species in the Gulf of Mexico. Front. Mar. Sci. 2018, 5, 336. [CrossRef]

68. Cuevas, E.; Guzmán-Hernández, V.; Uribe-Martínez, A.; Raymundo-Sánchez, A.; Herrera-Pavon, R. Identification of Potential Sea Turtle Bycatch Hotspots Using a Spatially Explicit Approach in the Yucatan Peninsula, Mexico. Chelonian Conserv. Biol. 2018, 17, 78-93. [CrossRef]

69. Diario Oficial de la Federación. PROYECTO de Modificación a La Norma Oficial Mexicana NOM-029-PESC-2006, Pesca Responsable de Tiburones y Rayas. Especificaciones Para Su Aprovechamiento; 2015. Available online: https://www.dof.gob. $\mathrm{mx} /$ nota_detalle.php?codigo=5381585\&fecha $=11 / 02 / 2015$ (accessed on 10 October 2021).

70. Finkbeiner, E.M.; Wallace, B.P.; Moore, J.E.; Lewison, R.L.; Crowder, L.B.; Read, A.J. Cumulative Estimates of Sea Turtle Bycatch and Mortality in USA Fisheries between 1990 and 2007. Biol. Conserv. 2011, 144, 2719-2727. [CrossRef]

71. Putman, N.F.; Hawkins, J.; Gallaway, B.J. Managing Fisheries in a World with More Sea Turtles. Proc. R. Soc. B 2020, $287,20200220$. [CrossRef]

72. Diario Oficial de la Federación. NORMA Oficial Mexicana NOM-002-SAG/PESC-2013, Para Ordenar el Aprovechamiento de las Especies de Camarón en Aguas Dejurisdicción Federal de los Estados Unidos Mexicanos. 2013. Available online: https:/ / www.dof.gob.mx/nota_detalle.php?codigo=5306294\&fecha=11/07/2013 (accessed on 10 October 2021).

73. Diario Oficial de la Federación. NORMA Oficial Mexicana NOM-061-SAG-PESC/SEMARNAT-2016, Especificaciones Técnicas de los Excluidores de Tortugas Marinasutilizados por la Flota de Arrastre Camaronera en Aguas de Jurisdicción Federal de los Estados Unidos Mexicanos; FAO: Rome, Italy, 2016.

74. Raborn, S.W.; Gallaway, B.J.; Cole, J.G.; Gazey, W.J.; Andrews, K.I. Effects of Turtle Excluder Devices (TEDs) on the Bycatch of Three Small Coastal Sharks in the Gulf of Mexico Penaeid Shrimp Fishery. N. Am. J. Fish. Manag. 2012, 32, 333-345. [CrossRef]

75. Willems, T.; Depestele, J.; De Backer, A.; Hostens, K. Ray Bycatch in a Tropical Shrimp Fishery: Do Bycatch Reduction Devices and Turtle Excluder Devices Effectively Exclude Rays? Fish. Res. 2016, 175, 35-42. [CrossRef]

76. Bojórquez-Tapia, L.A.; Ponce-Díaz, G.; Pedroza-Páez, D.; Díaz-de-León, A.J.; Arreguín-Sánchez, F. Application of Exploratory Modeling in Support of Transdisciplinary Inquiry: Regulation of Fishing Bycatch of Loggerhead Sea Turtles in Gulf of Ulloa, Mexico. Front. Mar. Sci. 2021, 8, 643347. [CrossRef]

77. Secretaría de Agricultura y Desarrollo Rural; Comisión Nacional de Acuacultura y Pesca. Plan de Acciones Emergentes Implementadas por el Gobierno Mexicano Para la Conservación de Tortugas Marinas, 1st ed.; SADER: Ciudad de Mexico, Mexico, 2021.

78. Yaghmour, F. Are oil spills a key mortality factor for marine turtles from the eastern coast of the United Arab Emirates? Mar. Pollut. Bull. 2019, 149, 110624. [CrossRef]

79. Diario Oficial de la Federación. ACUERDO Secretarial Número 249, por el Cual Se Expide la Versión Abreviada del Plan Nacional de Contingencia para Derrames de Hidrocarburos y Sustancias Nocivas Potencialmente Peligrosas en las Zonas Marinas Mexicanas. 2016. Available online: https://dof.gob.mx/nota_detalle.php?codigo=5458067\&fecha=24/10/2016 (accessed on 10 October 2021). 
80. Frazão Santos, C.; Michel, J.; Neves, M.; Janeiro, J.; Andrade, F.; Orbach, M. Marine Spatial Planning and Oil Spill Risk Analysis: Finding Common Grounds. Mar. Pollut. Bull. 2013, 74, 73-81. [CrossRef]

81. Fetissov, M.; Aps, R.; Goerlandt, F.; Jänes, H.; Kotta, J.; Kujala, P.; Szava-Kovats, R. Next-Generation Smart Response Web (NG-SRW): An Operational Spatial Decision Support System for Maritime Oil Spill Emergency Response in the Gulf of Finland (Baltic Sea). Sustainability 2021, 13, 6585. [CrossRef]

82. García-Aguilar, M.C.; Romo-Curiel, A.E.; Ramírez-León, M.R.; Ramírez-Mendoza, Z.; Fajardo-Yamamoto, A.; Sosa-Nishizaki, O. Modelación espacial de la coocurrencia entre los cetáceos y derrames de petróleo en el Golfo de México. In Vulnerabilidad Ecológica del Golfo de México Ante Derrames a Gran Escala; CICESE, CINVESTAV, UNAM: Ensenada, Mexico, 2020; Volume II, pp. 75-118.

83. Sosa-Nishizaki, O.; Romo-Curiel, A.E.; Ramírez-Mendoza, Z.; Fajardo-Yamamoto, A.; García-Aguilar, M.C.; Ramírez-León, M.R. Evaluación de la vulnerabilidad de los peces pelágicos ante escenarios de derrame de petróleo profundos en el Golfo de México. In Vulnerabilidad Ecológica del Golfo de México Ante Derrames a Gran Escala; CICESE, CINVESTAV, UNAM: Ensenada, Mexico, 2020; Volume II, pp. 119-152.

84. McDonald, T.; Schroeder, B.; Stacy, B.; Wallace, B.; Starcevich, L.; Gorham, J.; Tumlin, M.; Cacela, D.; Rissing, M.; McLamb, D.; et al. Density and Exposure of Surface-Pelagic Juvenile Sea Turtles to Deepwater Horizon Oil. Endanger. Species Res. 2017, 33, 69-82. [CrossRef]

85. Takeshita, R.; Sullivan, L.; Smith, C.; Collier, T.; Hall, A.; Brosnan, T.; Rowles, T.; Schwacke, L. The Deepwater Horizon Oil Spill Marine Mammal Injury Assessment. Endanger. Species Res. 2017, 33, 95-106. [CrossRef]

86. Wallace, B.; Stacy, B.; Rissing, M.; Cacela, D.; Garrison, L.; Graettinger, G.; Holmes, J.; McDonald, T.; McLamb, D.; Schroeder, B. Estimating Sea Turtle Exposures to Deepwater Horizon Oil. Endanger. Species Res. 2017, 33, 51-67. [CrossRef]

87. Scholz, A.; Bonzon, K.; Fujita, R.; Benjamin, N.; Woodling, N.; Black, P.; Steinback, C. Participatory Socioeconomic Analysis: Drawing on Fishermen's Knowledge for Marine Protected Area Planning in California. Mar. Policy 2004, 28, 335-349. [CrossRef]

88. Lopes, R.; Videira, N. Valuing Marine and Coastal Ecosystem Services: An Integrated Participatory Framework. Ocean Coast. Manag. 2013, 84, 153-162. [CrossRef]

89. Lauerburg, R.A.M.; Diekmann, R.; Blanz, B.; Gee, K.; Held, H.; Kannen, A.; Möllmann, C.; Probst, W.N.; Rambo, H.; Cormier, R.; et al. Socio-Ecological Vulnerability to Tipping Points: A Review of Empirical Approaches and Their Use for Marine Management. Sci. Total Environ. 2020, 705, 135838. [CrossRef] [PubMed]

90. Planque, B.; Mullon, C.; Arneberg, P.; Eide, A.; Fromentin, J.; Heymans, J.J.; Hoel, A.H.; Niiranen, S.; Ottersen, G.; Sandø, A.B.; et al. A Participatory Scenario Method to Explore the Future of Marine Social-ecological Systems. Fish Fish. 2019, $20,434-451$. [CrossRef]

91. Sowman, M.; Raemaekers, S. Socio-Ecological Vulnerability Assessment in Coastal Communities in the BCLME Region. J. Mar. Syst. 2018, 188, 160-171. [CrossRef]

92. Campbell, L.M.; Gray, N.J. Area Expansion versus Effective and Equitable Management in International Marine Protected Areas Goals and Targets. Mar. Policy 2019, 100, 192-199. [CrossRef]

93. Revuelta, O.; Hawkes, L.; León, Y.; Godley, B.; Raga, J.; Tomás, J. Evaluating the Importance of Marine Protected Areas for the Conservation of Hawksbill Turtles Eretmochelys imbricata Nesting in the Dominican Republic. Endanger. Species Res. 2015, 27, 169-180. [CrossRef]

94. Dawson, T.M.; Formia, A.; Agamboué, P.D.; Asseko, G.M.; Boussamba, F.; Cardiec, F.; Chartrain, E.; Doherty, P.D.; Fay, J.M.; Godley, B.J.; et al. Informing Marine Protected Area Designation and Management for Nesting Olive Ridley Sea Turtles Using Satellite Tracking. Front. Mar. Sci. 2017, 4, 312. [CrossRef]

95. Fuentes, M.M.P.B.; Gillis, A.J.; Ceriani, S.A.; Guttridge, T.L.; Van Zinnicq Bergmann, M.P.M.; Smukall, M.; Gruber, S.H.; Wildermann, N. Informing Marine Protected Areas in Bimini, Bahamas by Considering Hotspots for Green Turtles (Chelonia mydas). Biodivers. Conserv. 2019, 28, 197-211. [CrossRef]

96. Ferreira, L.C.; Thums, M.; Fossette, S.; Wilson, P.; Shimada, T.; Tucker, A.D.; Pendoley, K.; Waayers, D.; Guinea, M.L.; Loewenthal, G.; et al. Multiple Satellite Tracking Datasets Inform Green Turtle Conservation at a Regional Scale. Divers. Distrib. 2021, 27, 249-266. [CrossRef]

97. Roberts, K.E.; Smith, B.J.; Burkholder, D.; Hart, K.M. Evaluating the Use of Marine Protected Areas by Endangered Species: A Habitat Selection Approach. Ecol. Solut. Evid. 2021, 2, e12035. [CrossRef]

98. Shaver, D.J.; Frandsen, H.R.; George, J.A.; Gredzens, C. Green Turtle (Chelonia mydas) Nesting Underscores the Importance of Protected Areas in the Northwestern Gulf of Mexico. Front. Mar. Sci. 2020, 7, 673. [CrossRef]

99. Santos, A.J.B.; Bellini, C.; Santos, E.A.P.; Sales, G.; Ramos, R.; Vieira, D.H.G.; Marcovaldi, M.A.; Gillis, A.; Wildermann, N.; Mills, M.; et al. Effectiveness and Design of Marine Protected Areas for Migratory Species of Conservation Concern: A Case Study of Post-Nesting Hawksbill Turtles in Brazil. Biol. Conserv. 2021, 261, 109229. [CrossRef]

100. Diario Oficial de la Federación. Ley General del Equilibrio Ecológico y la Protección al Ambiente. 2021. Available online: http:/ / www.diputados.gob.mx/LeyesBiblio/pdf/LGEEPA.pdf (accessed on 10 October 2021).

101. Polanco Trujillo, L.D.A.; Gutiérrez Aguirre, M.A. Evaluación de enfoques metodológicos que analizan la efectividad de las áreas naturales protegidas de Quintana Roo, México. Teoría Prax. 2013, 9, 59-82. [CrossRef]

102. Cuevas, E.; Liceaga-Correa, M.A. Santuarios para tortugas marinas: Propuestas. In La Costa del Estado de Yucatán: Un Espacio de Reflexión Sobre la Relación Sociedad-Naturaleza, en el Contexto de Su Ordenamiento Ecológico Territorial; Plaza y Valdes: Ciudad de México, Mexico, 2014; Volume 1, pp. 303-310. 
103. Bolio Ortiz, H.J.; Bolio Ortiz, J.P.; Lara Farfan, F.D.L.L.; Hernandez Rugerio, A.D. Economía y sustentabilidad. Propuesta de evaluación del Programa de Ordenamiento Ecológico Costero de Yucatán. Rev. Logos Cienc. Tecnol. 2016, 8, 136-147. [CrossRef]

104. Fernández, R.J.L.; Gil, A.M.; Franco, J.F.S. La racionalidad económica en los nuevos criterios de regulación ecológica del Programa de Ordenamiento Ecológico del Territorio Costero del Estado de Yucatán. Paradig. Económico 2017, 9, 79-102.

105. Fish, M.R.; Côté, I.M.; Horrocks, J.A.; Mulligan, B.; Watkinson, A.R.; Jones, A.P. Construction Setback Regulations and Sea-Level Rise: Mitigating Sea Turtle Nesting Beach Loss. Ocean Coast. Manag. 2008, 51, 330-341. [CrossRef]

106. Crowder, L.; Norse, E. Essential Ecological Insights for Marine Ecosystem-Based Management and Marine Spatial Planning. Mar. Policy 2008, 32, 772-778. [CrossRef]

107. Toonen, H.M.; van Tatenhove, J.P.M. Marine Scaping: The Structuring of Marine Practices. Ocean Coast. Manag. 2013, 75, 43-52. [CrossRef]

108. Long, R.D.; Charles, A.; Stephenson, R.L. Key Principles of Marine Ecosystem-Based Management. Mar. Policy 2015, 57, 53-60. [CrossRef]

109. Maass, M.; Balvanera, P.; Bourgeron, P.; Equihua, M.; Baudry, J.; Dick, J.; Forsius, M.; Halada, L.; Krauze, K.; Nakaoka, M.; et al. Changes in Biodiversity and Trade-Offs among Ecosystem Services, Stakeholders, and Components of Well-Being: The Contribution of the International Long-Term Ecological Research Network (ILTER) to Programme on Ecosystem Change and Society (PECS). Ecol. Soc. 2016, 21, art31. [CrossRef]

110. Murphy, S.E.; Farmer, G.; Katz, L.; Troëng, S.; Henderson, S.; Erdmann, M.V.; Corrigan, C.; Gold, B.; Lavoie, C.; Quesada, M.; et al. Fifteen Years of Lessons from the Seascape Approach: A Framework for Improving Ocean Management at Scale. Conserv. Sci. Pract. 2021, 3, e423. [CrossRef]

111. Queffelec, B.; Bonnin, M.; Ferreira, B.; Bertrand, S.; Teles Da Silva, S.; Diouf, F.; Trouillet, B.; Cudennec, A.; Brunel, A.; Billant, O.; et al. Marine Spatial Planning and the Risk of Ocean Grabbing in the Tropical Atlantic. ICES J. Mar. Sci. 2021, fsab006. [CrossRef]

112. Esty, D.C. (Ed.) Global Environmental Governance: Options \& Opportunities; Yale School of Forestry \& Environmental Studies: New Haven, CT, USA, 2002; ISBN 978-0-9707882-2-1.

113. Herrmann, H. El papel de las organizaciones de la sociedad civil en el manejo costero de México. In El Manejo Costero en México; Universidad Autónoma de Quintana Roo: Campeche, Mexico, 2004; pp. 115-132.

114. Bultitude, K.; Rodari, P.; Weitkamp, E. Bridging the Gap between Science and Policy: The Importance of Mutual Respect, Trust and the Role of Mediators. Online J. Sci. Commun. 2012, 11, C01. [CrossRef]

115. Rodríguez Cardozo, L. El Desarrollo de Las ONG de México y Su Coincidencia Con Los Objetivos Para El Desarrollo Sostenible de Naciones Unidas. Ciriec-España 2017, 91, 59-84. [CrossRef]

116. Parviainen, T.; Lehikoinen, A.; Kuikka, S.; Haapasaari, P. How Can Stakeholders Promote Environmental and Social Responsibility in the Shipping Industry? WMU J. Marit. Aff. 2018, 17, 49-70. [CrossRef]

117. Rose, N.A.; Parsons, E.C.M. “Back off, Man, I'm a Scientist!" When Marine Conservation Science Meets Policy. Ocean Coast. Manag. 2015, 115, 71-76. [CrossRef]

118. Holmes, J.; Clark, R. Enhancing the Use of Science in Environmental Policy-Making and Regulation. Environ. Sci. Policy 2008, 11, 702-711. [CrossRef]

119. Fuentes, M.M.P.B.; Limpus, C.J.; Hamann, M. Vulnerability of Sea Turtle Nesting Grounds to Climate Change: VULNERABILITY ASSESSMENT FRAMEWORK. Glob. Chang. Biol. 2011, 17, 140-153. [CrossRef]

120. North, M.A. A method for implementing a statistically significant number of data classes in the jenks algorithm. In Proceedings of the 2009 Sixth International Conference on Fuzzy Systems and Knowledge Discovery, Tianjin, China, 14-16 August 2009; pp. 35-38.

121. Worton, B.J. Kernel Methods for Estimating the Utilization Distribution in Home-Range Studies. Ecology 1989, 70, 164-168. [CrossRef]

122. Schofield, G.; Dimadi, A.; Fossette, S.; Katselidis, K.A.; Koutsoubas, D.; Lilley, M.K.S.; Luckman, A.; Pantis, J.D.; Karagouni, A.D.; Hays, G.C. Satellite Tracking Large Numbers of Individuals to Infer Population Level Dispersal and Core Areas for the Protection of an Endangered Species. Divers. Distrib. 2013, 19, 834-844. [CrossRef]

123. Calenge, C. The Package "Adehabitat" for the R Software: A Tool for the Analysis of Space and Habitat Use by Animals. Ecol. Model. 2006, 197, 516-519. [CrossRef]

124. Comisión Nacional de Áreas Naturales Protegidas. Programa de Acción para la Conservación de la Especie Eretmochelys imbricata. 2009. Available online: https://www.gob.mx/cms/uploads/attachment/file/350214/PACE_Tortuga_Carey.pdf (accessed on 10 October 2021).

125. Comisión Nacional de Áreas Naturales Protegidas. Programa de Acción para la Conservación de la Especie Chelonia mydas. 2011. Available online: https:/ / www.gob.mx/conanp/documentos/programa-de-accion-para-la-conservacion-de-la-especietortuga-verde-negra-chelonia-mydas (accessed on 10 October 2021).

126. Saaty, T.L. Decision Making with the Analytic Hierarchy Process. Int. J. Serv. Sci. 2008, 1, 83-98. [CrossRef]

127. Goepel, K.D. Implementing the analytic hierarchy process as a standard method for multi-criteria decision making in corporate enterprises-A new AHP excel template with multiple inputs. In Proceedings of the International Symposium on the Analytic Hierarchy Process; Creative Decisions Foundation Kuala Lumpur: Kuala Lumpur, Malaysia, 2013. 
128. Diario Oficial de la Federación. Acuerdo por el Que Se da a Conocer la Actualización de la Carta Nacional Pesquera. 2012. Available online: https: / /www.dof.gob.mx/nota_detalle.php?codigo=5265388\&fecha=24/08/2012 (accessed on 10 October 2021).

129. Noguez-Fuentes, J.F.; Dreyfus-León, M.J. Análisis de la pesca de atún con palangre en el Golfo de México durante las fases de luna nueva y llena Analysis of the long-line tuna fishery in the Gulf of Mexico during the new and full moon phases. Hidrobiológica 2007, 17, 91-99.

130. Comision Nacional de Acuacultura y Pesca. Anuario Estadístico de Acuacultura y Pesca. 2014. Available online: https: //www.gob.mx/conapesca/documentos/anuario-estadistico-de-acuacultura-y-pesca (accessed on 10 October 2021).

131. Hawkes, L.; Broderick, A.; Godfrey, M.; Godley, B. Climate Change and Marine Turtles. Endanger. Species Res. 2009, 7, 137-154. [CrossRef]

132. Patrício, A.R.; Varela, M.R.; Barbosa, C.; Broderick, A.C.; Catry, P.; Hawkes, L.A.; Regalla, A.; Godley, B.J. Climate Change Resilience of a Globally Important Sea Turtle Nesting Population. Glob. Chang. Biol. 2019, 25, 522-535. [CrossRef]

133. Ocean Biology Processing Group. MODIS Aqua Level 3 SST MID-IR Monthly 4 Km Nighttime; Version 2014.0; PO.DAAC: Pasadena, CA, USA, 2016.

134. Fuentes, M.; Abbs, D. Effects of Projected Changes in Tropical Cyclone Frequency on Sea Turtles. Mar. Ecol. Prog. Ser. 2010, 412, 283-292. [CrossRef]

135. Dewald, J.R.; Pike, D.A. Geographical Variation in Hurricane Impacts among Sea Turtle Populations. J. Biogeogr. 2014, 41, 307-316. [CrossRef]

136. NOAA Hurricane Tracks: Cumulative-1950-2020. 2021. Available online: https://sos.noaa.gov/catalog/datasets/hurricanetracks-cumulative/ (accessed on 10 October 2021).

137. Servicio Meteorologico Nacional. Etapas de Evolución-Ciclones Tropicales. Available online: https://smn.conagua.gob.mx/es/ ciclones-tropicales / etapas-de-evolucion (accessed on 10 October 2021).

138. Department of Commerce through NOAA's Office for Coastal Management. Gulf of Mexico Vessel Density. 2013. Available online: https:/ / www.fisheries.noaa.gov/inport/item/48932 (accessed on 10 October 2021).

139. Comision Nacional de Hidrocarburos. Pozos y Licitaciones del Portal de Información Técnica v2.1.4 2018; Nacional de Hidrocarburos: Ciudad de México, Mexico, 2018.

140. Comisión Nacional de Hidrocarburos. Áreas Contractuales a Través de las Rondas Sujetas a Concurso por Licitación 2018; Comisión Nacional de Hidrocarburos: Ciudad de México, Mexico, 2018.

141. Nelms, S.E.; Piniak, W.E.D.; Weir, C.R.; Godley, B.J. Seismic Surveys and Marine Turtles: An Underestimated Global Threat? Biol. Conserv. 2016, 193, 49-65. [CrossRef]

142. Comision Nacional de Hidrocarburos. Zonas Sísmicas 2D y 3D 2018; Nacional de Hidrocarburos: Ciudad de México, Mexico, 2018.

143. Diario Oficial de la Federación Quinta Sección, Poder Ejecutivo, Secretaría de Energía. Decreto por el Que Se Establece la Zona de Salvaguarda Denominada Arrecifes de Coral del Golfo de México y Caribe Mexicano. 2016. Available online: https: / / www.dof.gob.mx/nota_detalle.php?codigo=5464472\&fecha=07/12/2016 (accessed on 10 October 2021). 